\title{
Article
}

\section{In Silico Identification of Small Molecules as New Cdc25 Inhibitors through the Correlation between Chemosensitivity and Protein Expression Pattern}

\author{
Antonino Lauria ${ }^{1, *} \mathbb{D}^{\mathbb{D}}$, Annamaria Martorana ${ }^{1}\left(\mathbb{D}\right.$, Gabriele La Monica ${ }^{1} \mathbb{D}$, Salvatore Mannino ${ }^{1}$,

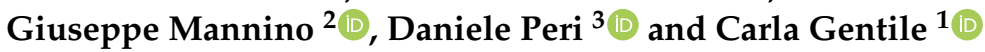 \\ 1 Dipartimento di Scienze e Tecnologie Biologiche Chimiche e Farmaceutiche "STEBICEF", \\ University of Palermo, Viale delle Scienze Ed. 17, I-90128 Palermo, Italy; \\ annamaria.martorana@unipa.it (A.M.); gabriele.lamonica01@unipa.it (G.L.M.); \\ manninosalvo5@gmail.com (S.M.); carla.gentile@unipa.it (C.G.) \\ 2 Department of Life Sciences and Systems Biology, Innovation Centre, University of Turin, \\ Via Quarello 15/A, I-10135 Turin, Italy; giuseppe.mannino@unito.it \\ 3 Dipartimento di Ingegneria, University of Palermo, Viale delle Scienze Ed. 6, I-90128 Palermo, Italy; \\ daniele.peri@unipa.it \\ * Correspondence: antonino.lauria@unipa.it
}

check for updates

Citation: Lauria, A.; Martorana, A.; La Monica, G.; Mannino, S.; Mannino, G.; Peri, D.; Gentile, C. In Silico Identification of Small Molecules as New Cdc25 Inhibitors through the Correlation between Chemosensitivity and Protein Expression Pattern. Int. J. Mol. Sci. 2021, 22, 3714. https:// doi.org/10.3390/ijms22073714

Academic Editor: Sugunadevi Sakkiah

Received: 11 March 2021

Accepted: 31 March 2021

Published: 2 April 2021

Publisher's Note: MDPI stays neutral with regard to jurisdictional claims in published maps and institutional affiliations.

Copyright: (c) 2021 by the authors. Licensee MDPI, Basel, Switzerland. This article is an open access article distributed under the terms and conditions of the Creative Commons Attribution (CC BY) license (https:// creativecommons.org/licenses/by/ $4.0 /)$.

\begin{abstract}
The cell division cycle 25 (Cdc25) protein family plays a crucial role in controlling cell proliferation, making it an excellent target for cancer therapy. In this work, a set of small molecules were identified as Cdc25 modulators by applying a mixed ligand-structure-based approach and taking advantage of the correlation between the chemosensitivity of selected structures and the protein expression pattern of the proposed target. In the first step of the in silico protocol, a set of molecules acting as Cdc25 inhibitors were identified through a new ligand-based protocol and the evaluation of a large database of molecular structures. Subsequently, induced-fit docking (IFD) studies allowed us to further reduce the number of compounds biologically screened. In vitro antiproliferative and enzymatic inhibition assays on the selected compounds led to the identification of new structurally heterogeneous inhibitors of Cdc25 proteins. Among them, J3955, the most active inhibitor, showed concentration-dependent antiproliferative activity against HepG2 cells, with GI 50 in the low micromolar range. When J3955 was tested in cell-cycle perturbation experiments, it caused mitotic failure by G2/M-phase cell-cycle arrest. Finally, Western blotting analysis showed an increment of phosphorylated Cdk1 levels in cells exposed to J3955, indicating its specific influence in cellular pathways involving Cdc25 proteins.
\end{abstract}

Keywords: molecular docking; antiproliferative activity; cell cycle; DRUDIT; HepG2; Cdc25

\section{Introduction}

The cell division cycle 25 (Cdc25) protein family, firstly identified in yeasts as a mitotic inducer [1], comprises three members (Cdc25A, B, and C) of dual-specificity protein phosphatases [2]. In mammalian cells, these proteins are involved in the activation of cyclin-dependent kinases 1 and 2 (Cdk1-2), through the dephosphorylation of specific threonine and tyrosine residues located in the ATP-binding loop (Tyr ${ }^{15}$ and Thr $^{14}$ ). All three forms cooperate to regulate cell division in human cells [3]. Particularly, Cdc25A controls both early and late cell-cycle transitions (G1-S, S, and G2-M) by acting on CyclinECdk2, CyclinA-Cdk2 and CyclinB-Cdk1, meanwhile Cdc25B and Cdc25C promote mitosis activating CyclinB-Cdk1 and CyclinA-Cdk2 (Figure 1) [4-6]. Following DNA damage and environmental stresses, $\mathrm{Cdc} 25$ proteins are phosphorylated and inactivated by Checkpoint 1-2 (Chk1-2) and MAPKAPK-2 kinases, determining their export outside the nucleus, and consequent cell-cycle arrest $[7,8]$. Considering their role in the activation of cyclin-Cdk complexes and, therefore, in cell-cycle progression, Cdc25s have become interesting targets 
in the search for anticancer drugs. In particular, due to the role of Cdc25s in the activation of cyclin-Cdk complexes downstream the G1 phase and involving cyclin A, cyclin M, and cyclin B, interference with Cdc25s activity could effectively block tumor cell proliferation. Indeed, although there are growth factor-dependent and nutrient-dependent checkpoints in the G1 phase, the vast majority of mutations that contribute to cell transformation involve genes regulating G1-progression. Those mutations make tumor cells autonomous from growth factor stimulation but, through the dysregulation of the cellular metabolism, also able to override nutritional sensing $[9,10]$. Consequently, while in the absence of growth factor instructions and nutrients cells commonly arrest at the G1 phase and undergo apoptosis, tumor cells are able to overcome all G1-checkpoints and progress along the G1 phase. In particular, in cancer cells, two signaling pathways activate G1 progression. The first involves ras mutations that, in a growth factor independent way, activate MAP kinase pathways increasing cyclin D expression and G1 complexes (cyclin D-Cdk4 and cyclin D-Cdk6) activation. The second is the mTOR pathway, which is highly sensitive to the presence of the energy and nutrients needed for activation of cyclin E complexes [11]. The possibility of intervention downstream of G1 checkpoints, through the inhibition of cyclin E, A, and B partners, strengthens $\mathrm{Cdc} 25$ inhibition as an anticancer strategy. From a structural point of view, human Cdc25A, B, and C include 524, 560, and 473 amino acids, respectively [12-14]. All three proteins comprise two main regions: the $\mathrm{N}$-terminal region, which is extremely variable and acts as a regulatory domain (as the site of phosphorylation and ubiquitination, or the sequencing of nuclear localization and exportation), and the C-terminal region, which is extremely homologous and contains the catalytic site $[15,16]$. The catalytic domain includes the $\mathrm{HCX}_{5} \mathrm{R}$ motif, characteristic of tyrosine phosphatase and composed of a highly conserved histidine; a catalytic cysteine (namely Cys ${ }^{430}, \mathrm{Cys}^{473}$, and $\mathrm{Cys}^{377}$ in Cdc25A, Cdc25B, and Cdc25C, respectively); five residues $\left(\mathrm{X}_{5}\right)$, whose amide groups form hydrogen bonds with phosphate residues; and a conserved arginine, required for binding to a phosphorylated amino acid of the substrate [13,14,17-19].

a)

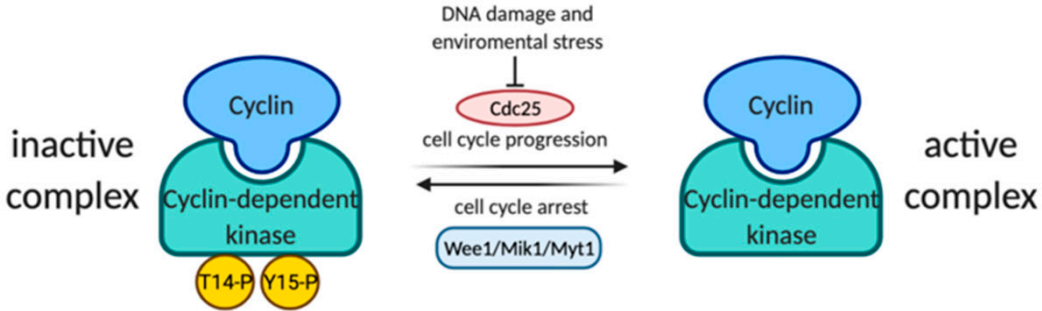

b)

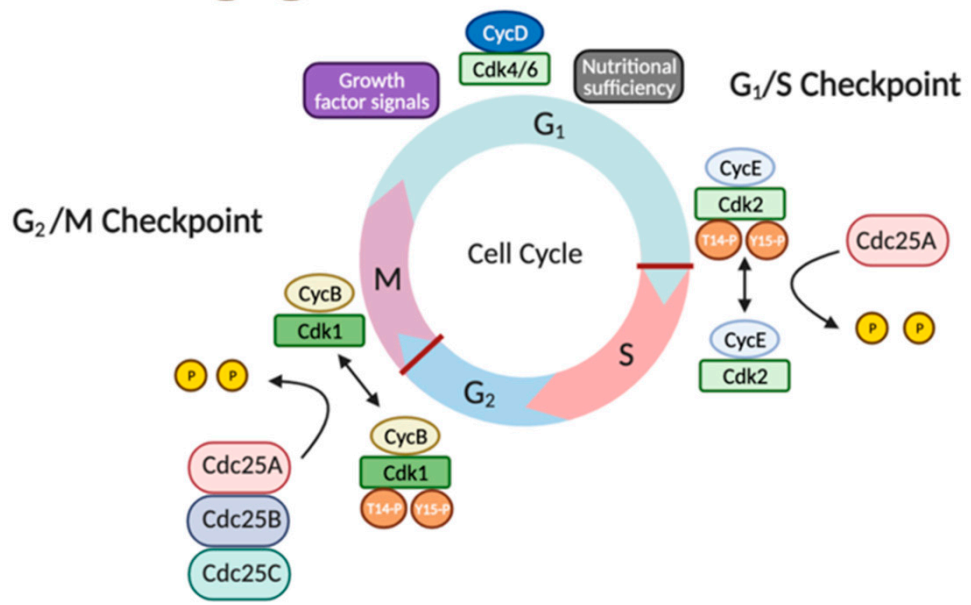

Figure 1. (a) Inactivation of cyclin-dependent kinases (Cdks) by the Wee1/Mik1/Myt1 protein kinase family through the phosphorylation of T14 and Y15. (b) The promotion of the entrance of cell division cycle $25 \mathrm{~A}(\mathrm{Cdc} 25 \mathrm{~A})$ in the S-phase cell cycle through the activation of the Cdk2/CycE complex (on the right); the promotion of mitosis by Cdc25A-B-C through the activation of the Cdk1/CycB complex (on the left). 
The analysis of the crystal structures of the catalytic domains of Cdc25A and Cdc25B (Figure 2, panel (a) and (b); Protein Data Bank (PDB) id: 1C25 and 1QB0, respectively) shows that the active sites appear flat and shallow, in contrast to other phosphatases $[20,21]$.

However, a well-ordered C-terminal helix adjacent to the catalytic pocket in the structure of Cdc25B contributes to the formation of the so-called "swimming pool", an extended and deep protein-sequence occupied by a significant amount of water molecules. This region contains several key residues that, in collaboration with those present in the catalytic domain, participate in the stabilization of protein-inhibitor complexes (Figure 2, panel (b)) $[15,22]$.

a)

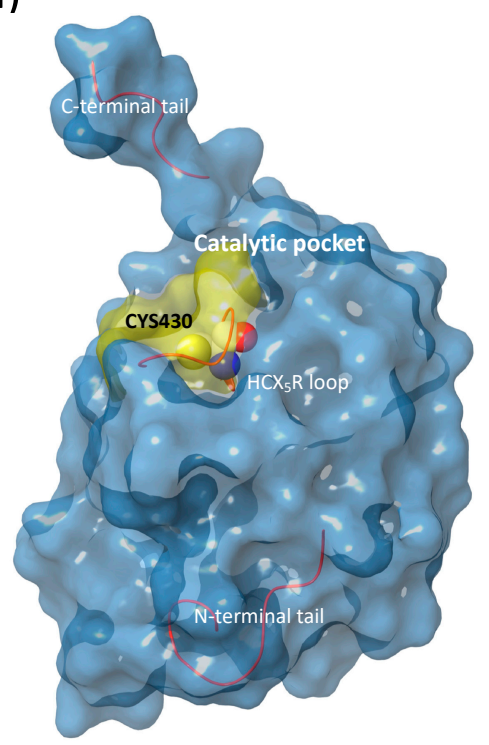

b)

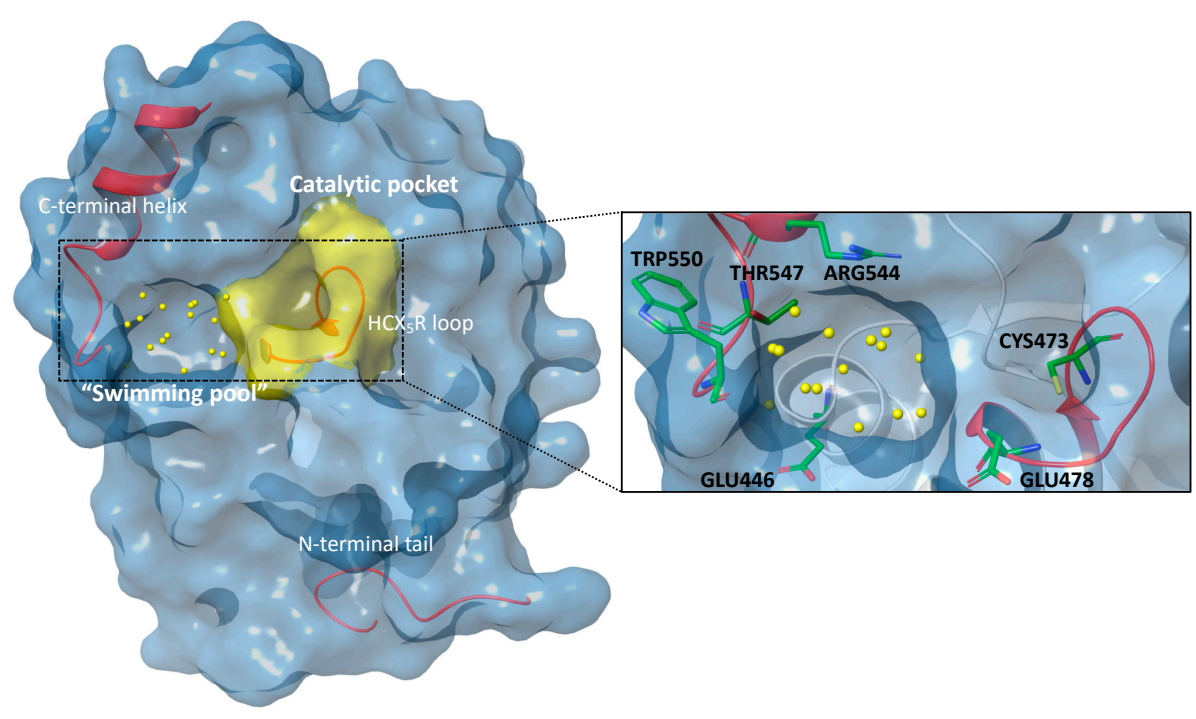

Figure 2. (a) Surface view of the Cdc25A crystal structure (PDB id: 1C25) [20] with the catalytic Cys430 in the $\mathrm{HCX}_{5} \mathrm{R}$ loop (Cdk representation) and the $\mathrm{C} / \mathrm{N}$ terminal tails highlighted. (b) Surface view of the Cdc25B crystal structure (PDB id: 1QB0) [21] with the catalytic $\mathrm{HCX}_{5} \mathrm{R}$ loop, the water molecules of the "swimming pool" region (yellow dots), the C-terminal helix, and the N-terminal tail highlighted. On the right, special focus is given to several of the most important residues (thick tube representation) within the catalytic pocket and the "swimming pool" involved in the catalytic process and the interactions with ligands.

As reported by Lavecchia et al. [23,24], several molecules have been developed as selective inhibitors of Cdc25s. The most studied classes are quinonoids, phosphate surrogates, and electrophilic entities [25]. In particular, NSC663284 and BN82685 (Figure 3), belonging to the quinonoid class, showed a remarkable Cdc25 inhibition activity, with $\mathrm{IC}_{50}$ values in the nanomolar range [26,27]. For many years, NSC663284 (Figure 3) has been used as a lead compound for the design of new Cdc25 inhibitors, with investigations made into its mechanism of action [28,29]. In 2017, Ge et al. identified by in silico analysis the "swimming pool" region as the potential binding site of NSC663284 in the Cdc25B phosphatase [30].

Moreover, Tao et al., in analyzing Cdc25s catalytic domains and pharmacophoric moieties [31], reviewed more suitable molecules (imidazopyridine CHEQ-2 [32], 1,2,4-triazole XDW-1 [33], sesquiterpene HB-21 [34], naphthyl-phenylamine (Figure 3, molecule 1) [35,36], chalcone (Figure 3, molecule 2) [37], 1,3-thiazolidin-4-ones (Figure 3, molecules 3 and 4) $[38,39])$, with interesting inhibitory activity on Cdc25 enzymes.

Due to the important role of Cdc25 as a checkpoint component of the cell cycle, the deregulation of its proteins at transcriptional, translational, and post translational levels can cooperate with oncogenic transformation and the progression of disease [25], especially in breast, ovarian, colorectal, esophageal, gastric, lung head, and neck cancer cells [40-47]. Furthermore, the overexpression of Cdc25A and Cdc25B is frequently linked with poor 
clinical prognosis [15,48]. For these reasons, Cdc25s can be considered attractive targets from the development of specific inhibitors for targeted therapeutic treatment [25,49].<smiles>Cc1nc2c(s1)C(=O)C=C(NCCN(C)C)C2=O</smiles>

NSC 663284
BN-82685<smiles>C=C1C(=O)O[C@H]2C[C@H](C)[C@H](CCC(C)=O)C=C[C@H]12</smiles>

HB-21<smiles>Cc1cc(C)c(-n2c(SCC(=O)c3ccc(O)c(O)c3)nc3cnccc32)c(C)c1</smiles>

CHEQ-2<smiles>Cc1ccc(-c2nnc(SCC(=O)c3ccc(O)c(O)c3)n2-c2ccc(Cl)cc2)cc1</smiles>

XDW-1

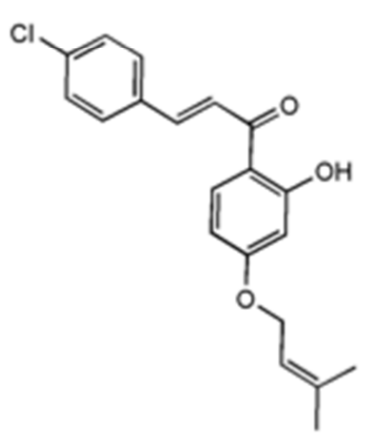

2

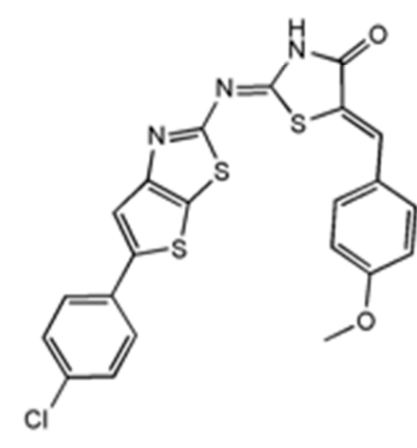

3<smiles>CCOC(=O)c1cccc(Nc2cc(OC)cc3ccccc23)c1</smiles>

1

Figure 3. The chemical structure of some well-known Cdc25 inhibitors.

Here, we propose an innovative in silico protocol based on the correlation between chemosensitivity and protein expression pattern. The use of the DRUDIT (DRUg Discovery Tools-www-drudit.com accessed on 31 March 2021) platform allows for the identification of several small molecules able to modulate the activity of a chosen specific target. In particular, focusing attention on Cdc25s enzymes, the application of the DRUDIT protocols permits the discovery of a new set of Cdc25s inhibitors. The robustness of our computational studies is consolidated by the interesting biological data on the modulation of Cdc25s enzymatic activity, the involvement of Cdks, and their actions related to cell-cycle control.

\section{Results and Discussion}

\subsection{Ligand-Based Studies}

The first step of the in silico protocol (Figure 4) consisted of building the Cdc25 template and integrating it as an external biological target in the DRUDIT platform. DRUDIT is a drug discovery web-service able to predict affinity to biological targets and the antiproliferative activity of input structures, through well-established computational protocols (www.drudit.com accessed on 31 March 2021) [50]. 


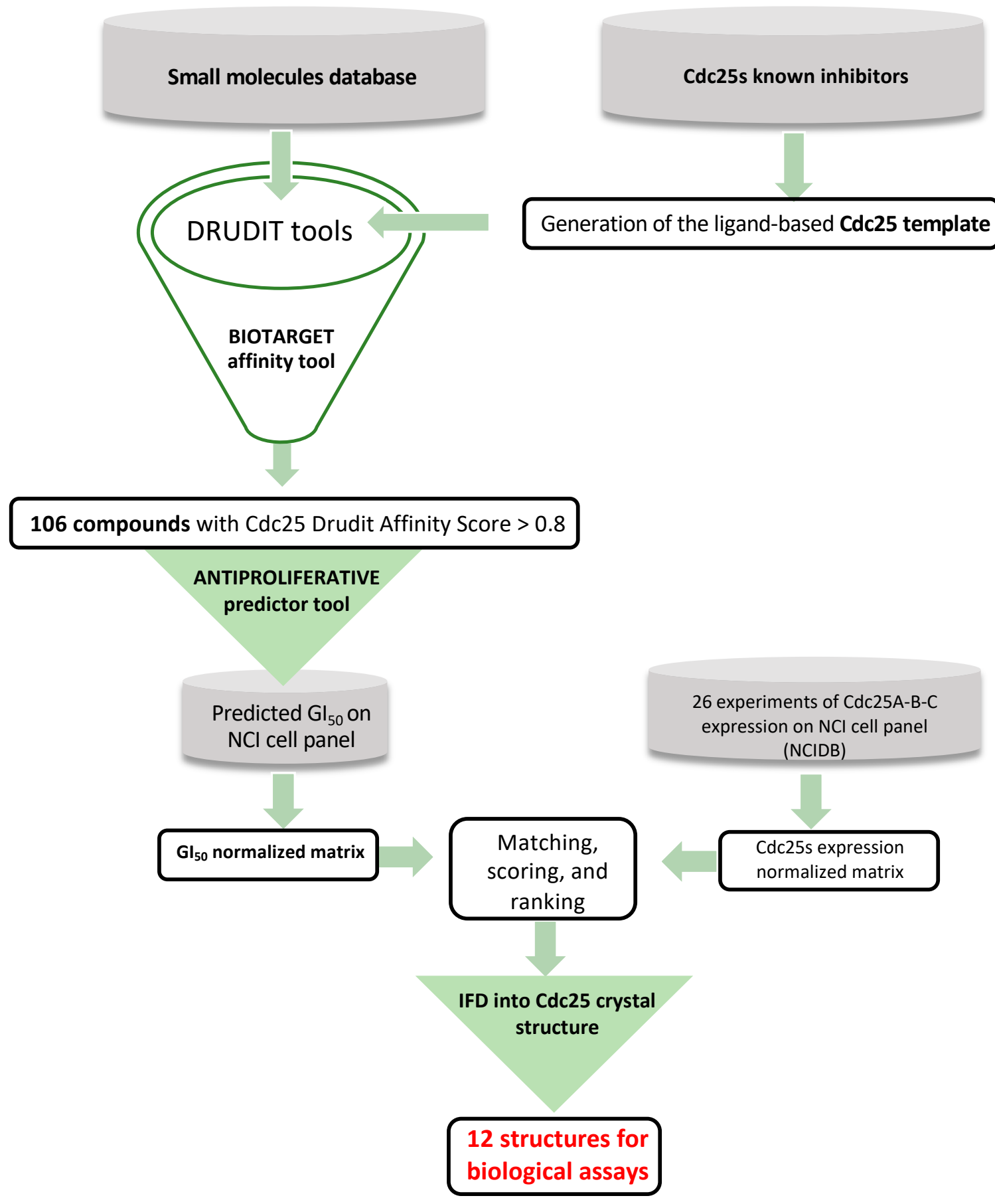

Figure 4. The in silico protocol aimed at identifying new Cdc25 inhibitors from a database of purchasable compounds (Sigma-Aldrich, St. Louis, MO, USA).

Then, a set of molecules containing 117 various $C d c 25$ s inhibitors with $\mathrm{IC}_{50}$ values lower than $10 \mu \mathrm{M}$ was collected from BindingDB [51] (Supplementary Material S1). The used ligand-based template of Cdc25 was based on molecular descriptors. The set of 117 structures was processed with MOLDESTO (the molecular descriptors tool, implemented in DRUDIT). The output matrix (structures versus molecular descriptors) was converted into a sequence (the template) of a pair of values for each molecular descriptor (Di) (Figure 5): mean $(\mu)$ and standard deviation $(\sigma)$. 


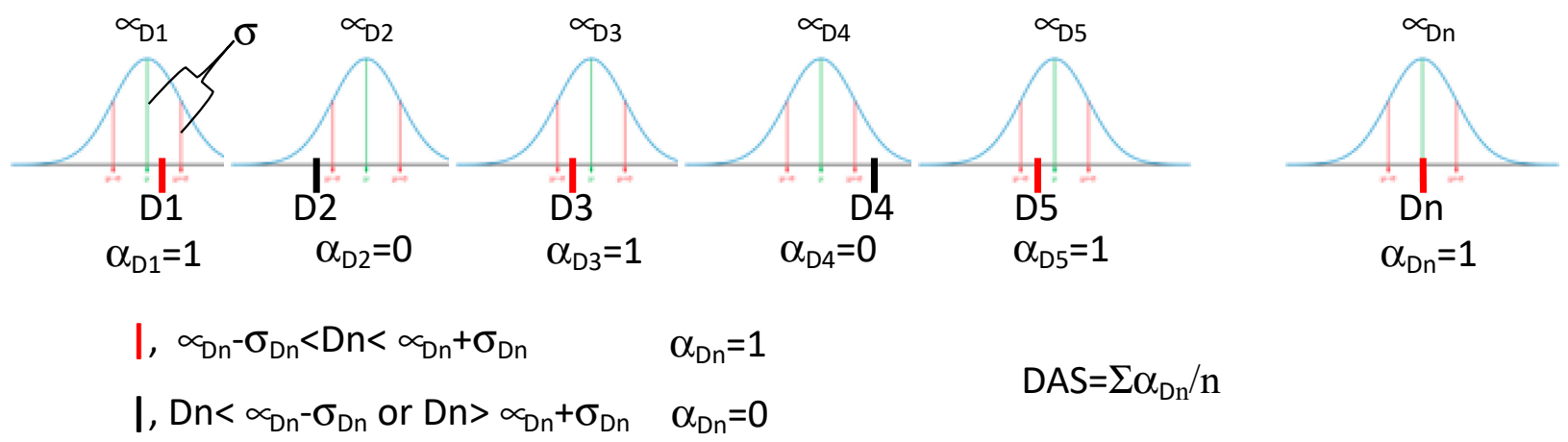

Figure 5. DAS (DRUDIT affinity score) calculation: D1, D2, . , Dn: molecular descriptor values for the input structure; n: number of molecular descriptors.

Then, the database of structures including more than 10,000 small molecules was submitted to the biological target finder tool in DRUDIT in order to rank each structure with a DRUDIT Affinity Score (DAS) against the Cdc25 template, as reported in Figure 5. The protocol assigns the $\alpha_{n}$ binary score to each molecular descriptor (Di). This value is 1 when the molecular descriptor $(\mathrm{Di})$ is in the range $\mu(\mathrm{Di}) \pm \sigma(\mathrm{Di})$, and 0 otherwise (Figure 5). The DAS score is assigned as $\Sigma \alpha_{n} / n$, thus it is in the range $0 \div 1$ (low $\div$ high affinity).

Supplementary Material S2 reports the full BIOTARGET matrix produced by DRUDIT and the ranking of the input structures against the Cdc25 template. The application of the 0.8 cutoffs to DAS reduced the database to 106 molecules (Supplementary Material S3).

In order to select the best structures for biological assay, further analysis by means of a new in silico protocol was conducted (Figure 4). This approach was based on the correlation between the antiproliferative activity values (expressed as $\mathrm{GI}_{50} \mathrm{~s}$ ) of the input structures and the expression patterns of target proteins against the full NCI60 cancer cell lines panel. The rationale behind this approach is the assumption that if the antiproliferative activity of a molecule is well linked with the protein expression pattern (high antiproliferative effect in a cancer cell line with a high expression of target protein/s and vice versa), it is very likely that its antiproliferative activity is due to the modulation of the target. This could be pursued thanks to the use of another NCI database that stores the expression patterns (EPs) of thousands of molecular targets from 60 different human tumor cell lines [52]. In the following, we denote the i-nth cell line with $\chi_{i}$. Therefore, a set of protein expression pattern data of Cdc25s against $\chi_{i}$ was downloaded from the NCI database. Then, 26 experiments reporting the measures of the expression pattern (EP) for each Cdc25 form against $\chi_{i}$ (10 for Cdc25A, 6 for Cdc25B, and 10 for Cdc25C, Supplementary Material S4) were selected, obtaining the molecular target expression pattern values $\left(\mathrm{P}_{\mathrm{i}}\right)$ and their mean value $\mu_{\mathrm{P}}$ (Figure 6). The deviation of each $P_{i}$ from the $\mu_{\mathrm{P}}$ normalized against the highest absolute value was computed to obtain the $\mathrm{NEP}_{\mathrm{i}}$ for each of the Cdc25 forms.

Since the experimental $\mathrm{GI}_{50}$ values for the selected structures were not measured, we used the antiproliferative predictor tool in DRUDIT, to predict the $\mathrm{GI}_{50}$ values against $\chi_{\mathrm{i}}$ for the input structures by means of molecular descriptors (Supplementary Material S5). Each of the 106 selected input structures was processed as follows. The mean value $\mu_{\mathrm{G}}$ of the predicted $\mathrm{GI}_{50}$ values $\mathrm{G}_{i}$ against $\chi_{i}$ was computed. Then, the deviation of each $\mathrm{G}_{i}$ from $\mu_{\mathrm{G}}$ was calculated and normalized against the highest absolute value in order to obtain NGI $_{50 \mathrm{i}}$ (Figure 6, Supplementary Material S4 and S5).

Then, the differences, $\delta_{\mathrm{i}}=\left|\mathrm{NEP}_{\mathrm{i}}-\mathrm{NGI}_{50 \mathrm{i}}\right|$, and the fitting score, $\Phi=\Sigma \delta_{\mathrm{i}}$, were computed for each of the Cdc25 A, B, and C form structures. Finally, each structure was ranked based on the mean of the three $\varphi$ values $(\Phi)$. The highest scoring structures were those that reported lower values of $\Phi$, indicating the best correlation between protein expression pattern and sensitivity. Among the 106 structures, the first 24 were selected for structure-based study in the next in silico step (Figure 7, Supplementary Material S6). 


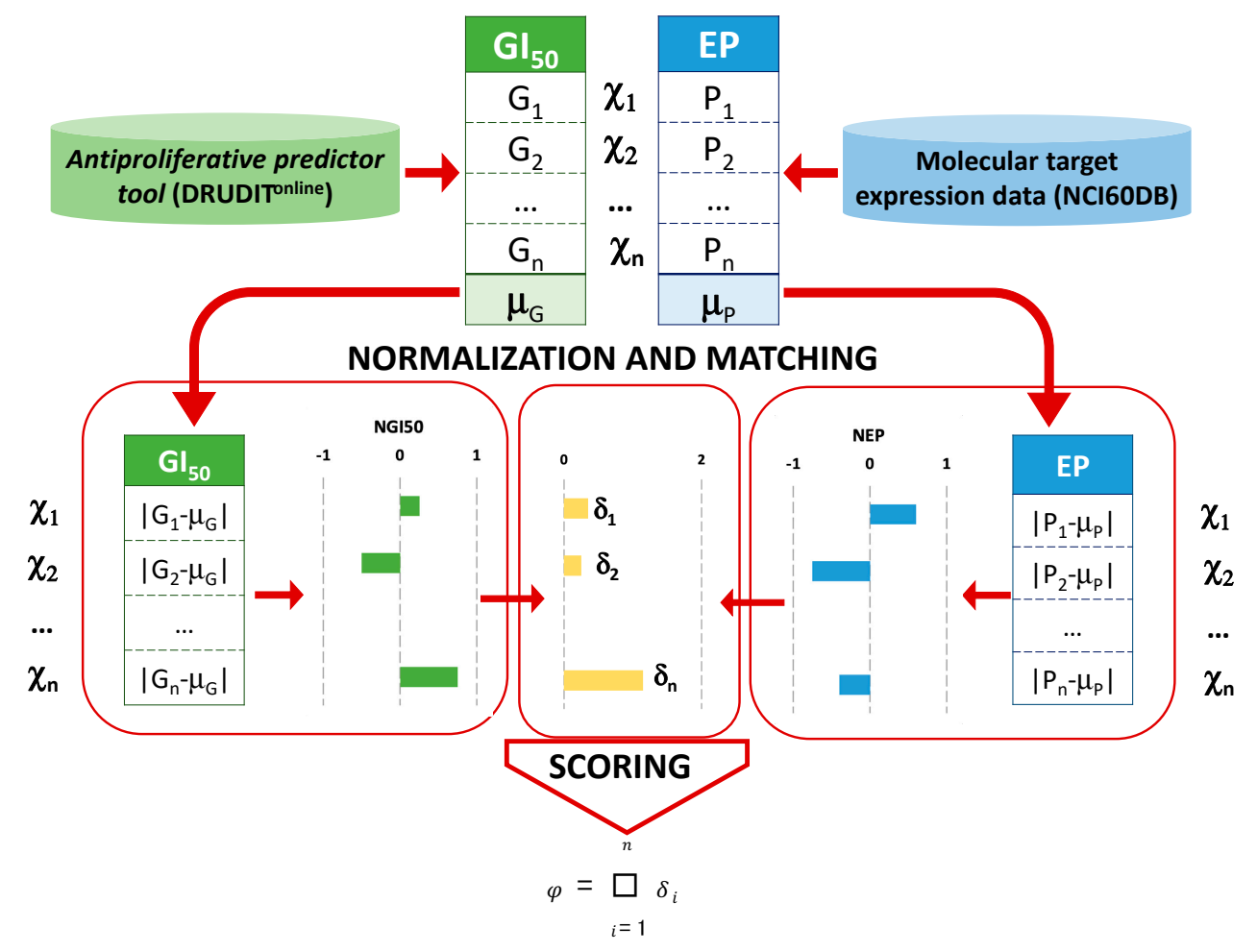

Figure 6. Workflow for the assessment of the correlation between the antiproliferative activity values (expressed as $\mathrm{GI}_{50} \mathrm{~s}$ ) and expression patterns (Eps) on NCI60 cancer cell lines $\chi_{\mathrm{i}}$.

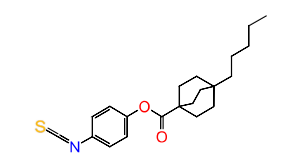

370053

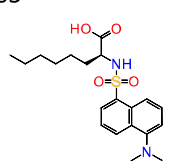

D0268

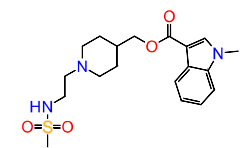

G5918

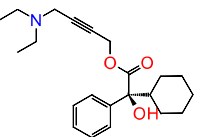

00288000

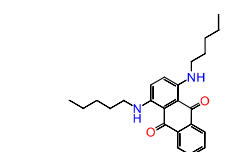

391557

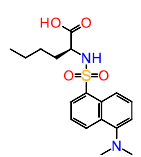

D0756

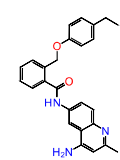

J3955

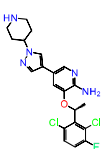

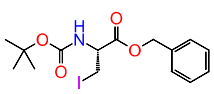

406252

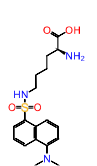

D9006

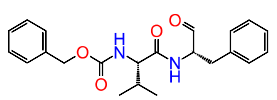

M6690

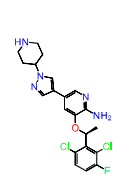

PZ0240

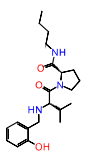

798827

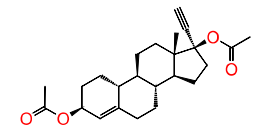

E7263

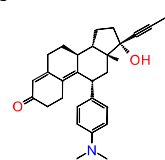

M8046

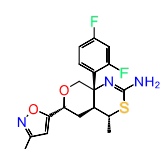

PZ0261

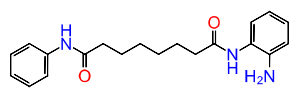

B8063

D0143

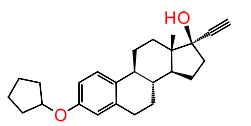

E7887

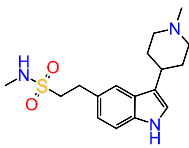

N1415

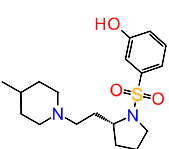

S7389
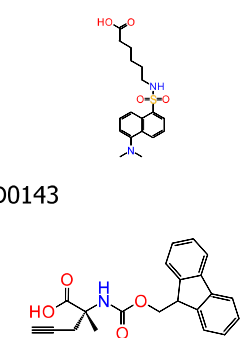

F5312

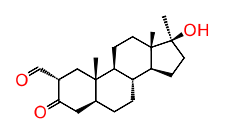

00380

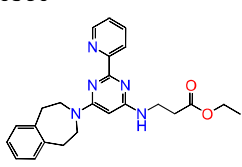

SML0701

Figure 7. Representation of the chemical structure of the 24 small molecules selected as potential Cdc25s modulators and identified by the correlation between protein expression pattern (EPs) and antiproliferative activity $\left(\mathrm{GI}_{50} \mathrm{~s}\right)$ data.

\subsection{Structure-Based Studies}

The top 24 ranked ligands were further analyzed through structure-based study in order to select the compounds that best fitted to the binding site of Cdc25s. A range of possibilities for the binding site and binding mode of various structures into Cdc25s binding sites were reported in the literature, identifying two potential binding regions for the target inhibition: the "swimming pool" pocket and the substrate catalytic site 
(Figure 2) $[22,53,54]$. Furthermore, the suggested binding modes are various and they are obtained by the use of different molecular docking programs. For these reasons, and in order to cover all the possibilities, the docking grid was extended to both the catalytic and the "swimming pool" zones. Then, the 24 top-scoring molecules (Figure 7) were submitted to induced-fit study into the binding site of Cdc25B (see material and methods), whose crystal structure is available at the PDB as 1QB0 [21]. The induced-fit docking (IFD) results (Table 1) allowed for the selection of the top $50 \%$ of scored molecules for their investigation, as Cdc25s modulators, in wet screenings (bold in Table 1).

Table 1. Ligand and structure-based output results. DAS: DRUDIT affinity score; IFD: induced-fit docking.

\begin{tabular}{|c|c|c|c|c|}
\hline Cpd ${ }^{\#}$ & DAS & Docking Score & Prime Score & IFD Score \\
\hline 370053 & 0.824 & -6.067 & -5898.431 & -396.631 \\
\hline 391557 & 0.832 & -7.523 & -5938.661 & -398.557 \\
\hline 406252 & 0.842 & -5.433 & -5950.001 & -398.655 \\
\hline 798827 & 0.81 & -10.426 & -5945.922 & -403.413 \\
\hline B8063 & 0.824 & -8.394 & -5988.759 & -401.905 \\
\hline D0143 & 0.8 & -6.39 & -5915.872 & -398.467 \\
\hline D0268 & 0.822 & -6.625 & -5846.066 & -398.491 \\
\hline D0756 & 0.802 & -5.706 & -5925.995 & -398.421 \\
\hline D9006 & 0.806 & -6.233 & -5900.211 & -398.686 \\
\hline E7263 & 0.838 & -7.806 & -5939.597 & -398.736 \\
\hline E7887 & 0.82 & -8.818 & -5930.375 & -399.411 \\
\hline F5312 & 0.854 & -7.861 & -5973.455 & -401.703 \\
\hline G5918 & 0.814 & -7.472 & -5939.175 & -401.572 \\
\hline J3955 & 0.814 & -7.846 & -5957.553 & -400.302 \\
\hline M6690 & 0.836 & -8.443 & -5995.928 & -404.249 \\
\hline M8046 & 0.810 & -6.245 & -5931.352 & -396.262 \\
\hline N1415 & 0.822 & -4.851 & -5934.807 & -398.316 \\
\hline O0288000 & 0.826 & -10.547 & -5942.99 & -402.148 \\
\hline O0380 & 0.800 & -7.945 & -5958.136 & -398.68 \\
\hline PZ0191 & 0.824 & -9.439 & -5997.385 & -405.087 \\
\hline PZ0240 & 0.808 & -9.103 & -5983.756 & -404.548 \\
\hline PZ0261 & 0.820 & -5.406 & -5967.376 & -397.571 \\
\hline S7389 & 0.892 & -7.65 & -5875.452 & -398.318 \\
\hline SML0701 & 0.834 & -7.211 & -6128.861 & -407.205 \\
\hline
\end{tabular}

The top $50 \%$ of the scored molecules selected for the in vitro screenings are shown in bold.

Further analyses were performed on the selected hits considering a series of wellconsolidated parameters for the search of bioactive compounds, such as PAINS filters [55]; Lipinski's rule [56]; Veber rules [57]; and Egan rules [58]. Thus, the 12 previously selected molecules were submitted to SwissADME web-tools (http:/ / www.swissadme.ch accessed on 31 March 2021) [59]. The results reported in Table 2 show that, generally, the selected compounds match expectations with regards to their bioactivity. In particular, seven of the twelve structures have no violations, and only the Cpd 798827 presented two rule violations (PAINs and Veber).

Table 2. Drug-likeness parameters calculated for the selected compounds.

\begin{tabular}{cccccccccc}
\hline Cpd $^{*}$ & $\mathbf{P}$ & L & V & E & Cpd & P & L & V & E \\
\hline M6690 & 0 & 0 & 1 & 0 & PZ0240 & 0 & 0 & 0 & 0 \\
E7887 & 0 & 1 & 0 & 0 & PZ0191 & 0 & 0 & 0 & 0 \\
E7263 & 0 & 1 & 0 & 0 & J3955 & 0 & 0 & 0 & 0 \\
F5312 & 0 & 0 & 0 & 0 & 798827 & 1 & 0 & 1 & 0 \\
O0288000 & 0 & 0 & 0 & 0 & SML0701 & 0 & 0 & 0 & 0 \\
B8063 & 0 & 0 & 1 & 0 & G5918 & 0 & 0 & 0 & 0
\end{tabular}

* P: PAINS \#alert; L: Lipinski \#violations; V: Veber \#violations; E: Egan \#violations. 
Finally, the molecular descriptors matrix of the selected compounds was merged with that of the known Cdc25 inhibitors used to build the template, and multivariate analysis was performed. From this analysis emerged the method behind which the protocol was able to select molecules that are structurally different from those used in the building of the template. In fact, by applying principal component analysis (PCA) to the matrix (Supplementary Material S7), the visual inspection on the PCA 2D representation (Figure 8) allows for the identification of a central region where the selected structures are clustered, while the template structures are spread in the left or right area, in approximatively two clusters.

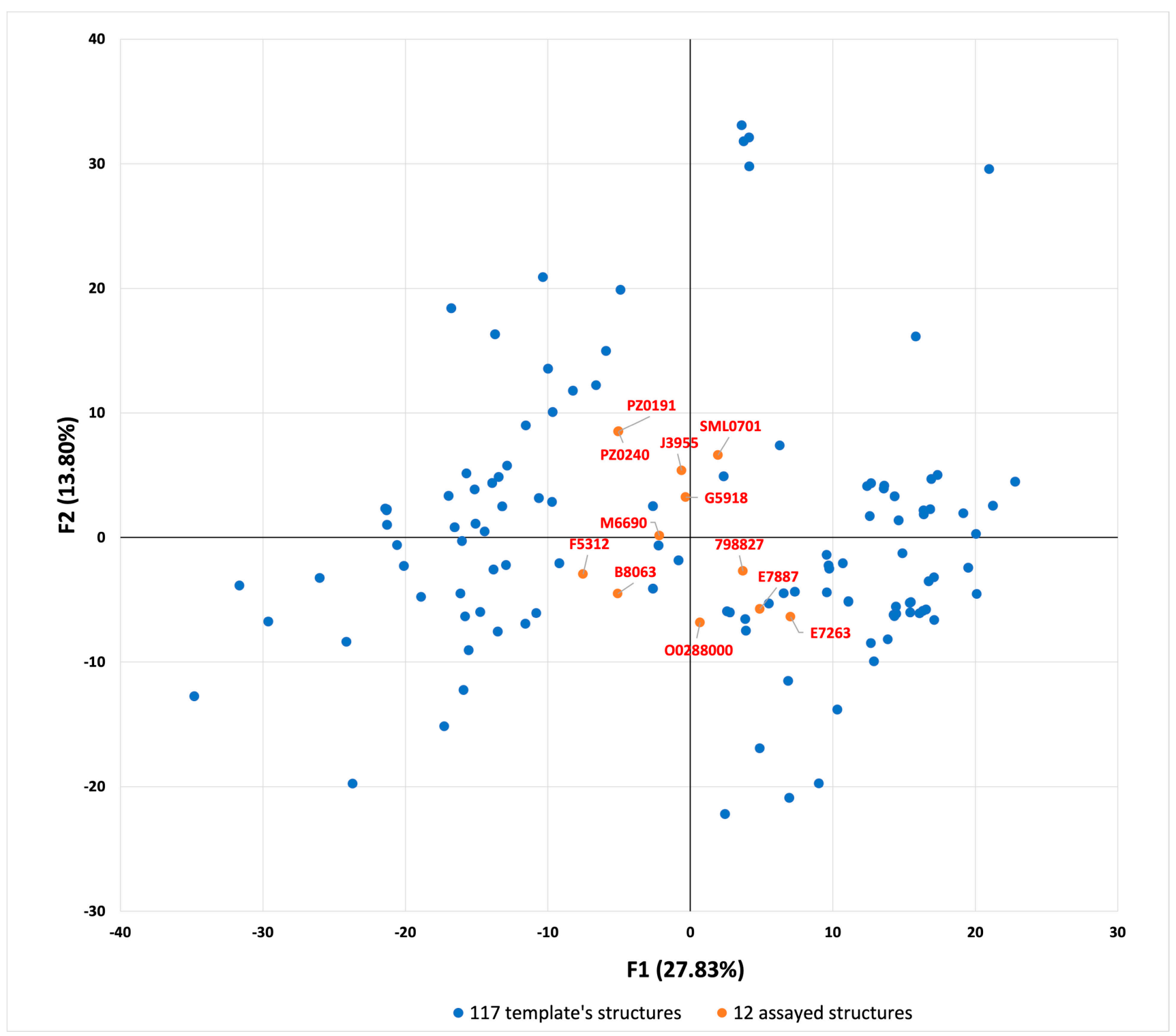

Figure 8. Principal component analysis (F1 versus F2) applied to the molecular descriptor matrix of the selected compounds merged with the known Cdc25 inhibitors.

These results suggested that the ligand-based step of the protocol was able to select molecules endowing various scaffolds, in a different manner from that of the classical ligand-based methods. 


\subsection{Cdc25s Phosphatase Inhibitory Activity}

The selected compounds, whose structures and purity consistency were checked by HMRS analysis (Supporting Information S8), were tested in a dose-response assay on Cdc25 phosphatases. Eight of the twelve tested compounds (798827, B8063, E7887, F5312, J3955, M6690, O0288000, and PZ0240) inhibited in vitro the recombinant human Cdc25s phosphatases in a concentration-dependent manner. Concerning Cdc25A, the recorded $\mathrm{IC}_{50}$ values ranged from $1.12 \pm 0.09$ to $19.88 \pm 2.07 \mu \mathrm{M}$ (Table 3 and Supplementary Material S9). A similar pattern of inhibition was observed on Cdc25B and Cdc25C, even though a lower inhibition activity was displayed. The determined $\mathrm{IC}_{50}$ values for the most active compounds (E7887 and J3955) were comparable to the $\mathrm{IC}_{50}$ of the menadione, a Cdc25 quinonoid inhibitor used as a positive control in this study. On the contrary, the compounds E7263, G5918, PZ0191, and SML0701 did not reduce the activity of the phosphatase in the tested concentration range $(0.25-25 \mu \mathrm{M})$.

To the best of our knowledge, this is the first time that the Cdc25 inhibition activity of the tested compounds has been assayed. On the other hand, among the tested compounds, phosphatase inhibition activity is documented only for the clinically approved anticancer agent PZ0240 ((S)-crizotinib), which, in addition to its effect as a kinase inhibitor, is a stereospecific inhibitor of 2-hydroxy-dATP diphosphatase1 or MutT homolog 1 (MHT1) phosphatase [60], an enzyme required for the survival of cancer cells and involved in DNA repair processes to maintain genome stability under oxidative stress [61,62].

\subsection{Antiproliferative Screening}

To assess Cdc25 inhibitors in cells, the antiproliferative activity of the most promising compounds (798827, B8063, E7887, F5312, J3955, M6690, O0288000, and PZ0240) was evaluated on the HepG2 tumor cell line for $48 \mathrm{~h}$ via MTT-based cell viability assay. Three of the tested compounds (E7887, J3955, and PZ0240) showed concentration-dependent antiproliferative activity with $\mathrm{GI}_{50}$ in the low micromolar range (Table 4). On the contrary, the other molecules showed low or no activity in the tested concentration range. Moreover, among the inactive molecules, only for B8063 (BML-210), an inhibitor of histone deacetylase, the antiproliferative activity was previously reported on leukemic and cervical cancer cells $[63,64]$.

No data on the antiproliferative activity of E7887 (quinestrol), a synthetic estrogen used to treat postmenopausal syndrome and as a contraceptive component [65], had been reported in the literature prior to this study. Instead, the antiproliferative activity of J3955, a high-affinity and selective opioid receptor-like 1 (ORL1) receptor antagonist, was recently explored and its effects on osteosarcoma and hepatocarcinoma cells were demonstrated [66,67].

However, while we recorded a $\mathrm{GI}_{50}$ value of $1.50 \pm 0.37 \mu \mathrm{M}$ on HepG2 cells, the data available in the literature showed antiproliferative activity at much higher concentrations. In particular, Zhao B. and Hu T. found antiproliferative effects on HepG2 cells at concentrations above $20 \mu \mathrm{M}$ [67]. The reason for this discrepancy is probably due to the dissimilar cancer cell lines used for the analysis, with genetic and mutational profiles that are not completely superimposable.

In their studies, Zhao B. and Hu T. employed a type of HepG2 cells characterized by deep invasive properties. In our assays, we used poorly invasive cells with phenotypic requirements generally described in the literature for the HepG2 line. The low invasiveness of hepatocarcinoma cells is justified by a high expression of epithelial cadherins and by a lack of expression of mesenchymal cadherins [68].

The biological results suggested an interesting correlation between the antiproliferative effect on HepG2 cell lines and the inhibition properties of Cdc25 enzymes. In particular, compounds E7887 and J3955, characterized by the highest Cdc25 modulation activities (Table 3) showed notable cellular growth inhibition with $\mathrm{GI}_{50}$ values of $13.03 \pm 0.85$ and $1.50 \pm 0.37 \mu \mathrm{M}$, respectively (Table 4 ). 
Table 3. $\mathrm{IC}_{50}$ values of the selected compounds for the inhibition of $\mathrm{Cdc} 25 \mathrm{~A}, \mathrm{~B}$, and $\mathrm{C}$ phosphatases.

\begin{tabular}{cccc}
\hline Cpd & Cdc25A $(\boldsymbol{\mu M})$ & Cdc25B $(\mu \mathbf{M})$ & Cdc25C $(\mu \mathbf{M})$ \\
\hline 798827 & $12.02 \pm 1.03$ & $16.73 \pm 1.71$ & $14.43 \pm 1.33$ \\
B8063 & $15.23 \pm 1.37$ & $18.03 \pm 1.11$ & $17.73 \pm 1.36$ \\
E7263 & $>25$ & $>25$ & $>25$ \\
E7887 & $7.41 \pm 0.79$ & $8.91 \pm 1.02$ & $8.12 \pm 0.87$ \\
F5312 & $17.12 \pm 1.91$ & $19.11 \pm 1.88$ & $19.34 \pm 1.65$ \\
G5918 & $>25$ & $>25$ & $>25$ \\
J3955 & $1.12 \pm 0.09$ & $2.19 \pm 0.07$ & $2.22 \pm 0.07$ \\
M6690 & $17.16 \pm 1.14$ & $19.83 \pm 1.41$ & $17.79 \pm 1.83$ \\
O0288000 & $12.03 \pm 1.17$ & $14.14 \pm 1.51$ & $12.93 \pm 1.56$ \\
PZ0191 & $>25$ & $>25$ & $>25$ \\
PZ0240 & $19.88 \pm 2.07$ & $22.13 \pm 2.17$ & $20.37 \pm 2.34$ \\
SML0701 & $>25$ & $>25$ & $>25$ \\
Menadione & $4.48 \pm 0.17$ & $5.97 \pm 0.75$ & $4.49 \pm 0.27$
\end{tabular}

All values are the mean \pm S.D. of three independent determinations.

Table 4. The antiproliferative activity of the selected compounds at $48 \mathrm{~h}$ against HepG2 cell lines expressed as $\mathrm{GI}_{50}$ values $\left(\mathrm{GI}_{50} \pm \mathrm{SE}(\mu \mathrm{M})\right)$.

\begin{tabular}{cc}
\hline Cpd & GI $_{\mathbf{5 0}}(\boldsymbol{\mu M})$ \\
\hline 798827 & $>25$ \\
B8063 & $23.03 \pm 2.13$ \\
E7887 & $13.03 \pm 0.85$ \\
F5312 & $>25$ \\
J3955 & $1.50 \pm 0.37$ \\
M6690 & $20.01 \pm 1.87$ \\
O0288000 & $>25$ \\
PZ0240 & $7.35 \pm 0.77$ \\
\hline
\end{tabular}

The antiproliferative data, observed for the PZ0240 compound ( $\mathrm{GI}_{50}$ values $\left.7.35 \pm 0.77 \mu \mathrm{M}\right)$, are in line with its anticancer therapeutic use as tyrosine kinase and an MTH1 inhibitor. The observed Cdc25s inhibition activities do not exclude multi-target effects.

\subsection{Cell Cycle Distribution and Phosphorylation of Cdk1}

Based on the results described above, among all the tested molecules compound J3955 was identified as the one with the best inhibition effect on the Cdc25 phosphatase and with the highest antiproliferative activity. With the aim to further elucidate the mechanism of action of J3955 as a Cdc25 inhibitor, we performed flow cytometric analysis on HepG2 cells.

Since the Cdc25s enzymes control the cell cycle through the dephosphorylation of their natural substrate Cdks, the inhibition of Cdc25s results in the hyperphosphorylation of Cdks with consequent cell-cycle arrest. Therefore, the impact of cell exposure to J3955 on cell-cycle progress and the phosphorylation state of Cdks was investigated.

The flow cytometric analysis, for cell-cycle perturbation experiments, was executed in order to detect the shifts in cell-cycle distribution before a significant number of cells underwent apoptosis. The working concentrations of the compound J3955 were fixed at $1 \times$ and $2 \times$ of its $\mathrm{GI}_{50}$ value used in the cell proliferation assay at $48 \mathrm{~h}$.

The histograms in Figure 9 represent the percentage of cells in respective cell-cycle phases (G1, S, and G2/M), along with the percentage of cells in the sub-G1 (dead cells) obtained by flow cytometry after either a $12 \mathrm{~h}$ (Figure 9, panel A) or a $24 \mathrm{~h}$ (Figure 9, panel B) treatment. In the absence of J3955, HepG2 cells showed a normal diploid distribution with fast proliferation characteristics, with S + G2/M phase cells accounting for about $45 \%$ of the total cells. A $12 \mathrm{~h}$ treatment with J3955 arrested the cell cycle at the G2/M phase in a dose-dependent manner (Figure 9A). An increase in G2/M phase cells from $24 \%$ to $27 \%$ and from $24 \%$ to $36 \%(p<0.0001)$ was observed as a result of cell exposure to J3955 at $1 \times \mathrm{GI}_{50}(1.5 \mu \mathrm{M})$ and at $2 \times \mathrm{GI}_{50}(3.0 \mu \mathrm{M})$, respectively. The cell accumulation in the $\mathrm{G} 2 / \mathrm{M}$ 
cell-cycle phase was coupled to a decrease in the G0/G1 phase cells rather than a decrease in the $S$ phase.

A similar trend was observed after $24 \mathrm{~h}$ treatments with $\mathrm{J} 3955$ at $1 \times \mathrm{GI}_{50}(1.5 \mu \mathrm{M})$ : G2/M phase cells increase from $25 \%$ to $32 \%(p<0.0001)$ (Figure 9B). However, when the cells were exposed to J3955 at $2 \times \mathrm{GI}_{50}$ for $24 \mathrm{~h}$, a new sub-G0/G1 population appeared, indicative of apoptotic cells, with a parallel decrease of the population in the G2/M phase (Figure 9B).

Dephosphorylated Cdc25s are activated by both Cdk1 and Cdk2. Then, Cdc25s activate both the G1/S transition and S-phase Cdk-cyclin complexes (Cdk2-cyclinE and Cdk2/cyclinA), but also the Cdk1/cyclin B complex involved in the G2/M transition. Consequently, although Cdc25 inhibition induces cell-cycle arrest, the stage of cell-cycle block by Cdc25 inhibitors cannot be predicted and literature data show that it is cell line-dependent.

A

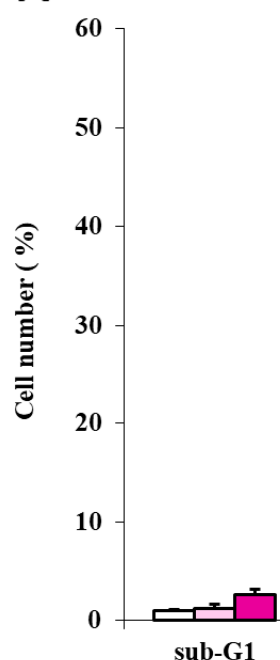

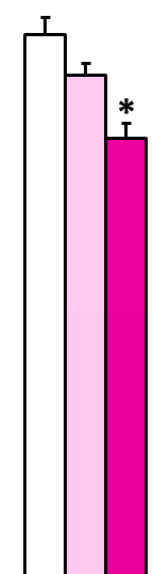

G0/G1
B

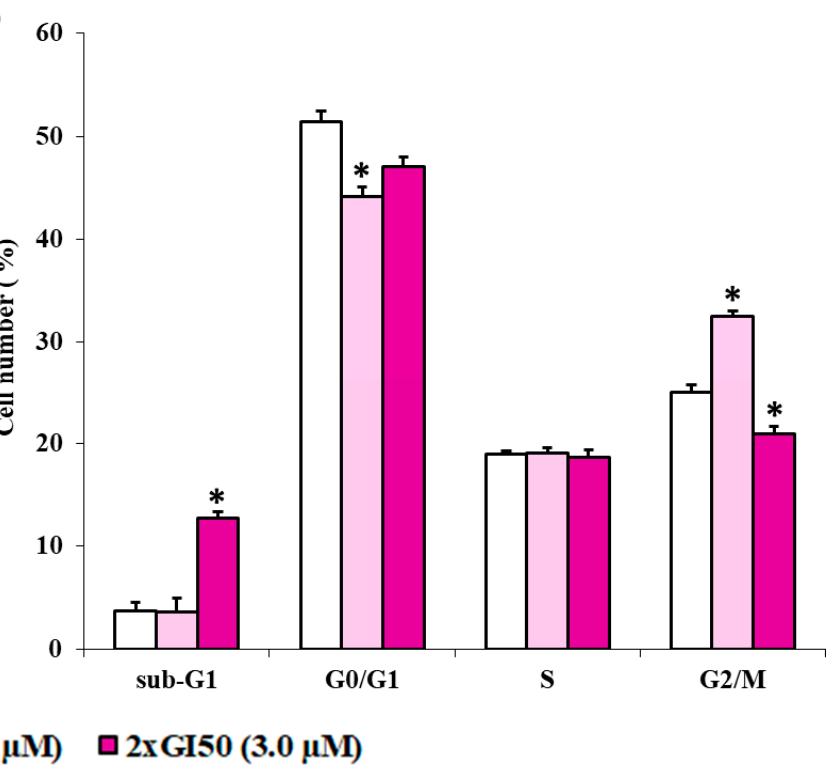

Figure 9. The effects of $\mathrm{J} 3955$ at $2 \times$ and $1 \times$ its $\mathrm{GI}_{50}$ value on the cell-cycle distribution of HepG2 cells following $12 \mathrm{~h}$ (A) and $24 \mathrm{~h}$ (B) treatments. Results are expressed as the mean of two independent experiments, performed in duplicate. Statistical analyses were performed using the Student's $t$-test to determine the differences between the datasets. * Denotes significant differences $(p<0.0001)$ from untreated cells (control).

In the same cell line, it is observed that several molecules displaying Cdc25 inhibition effects trigger different cell-cycle arrests. For example, Kabakci et al., studying the inhibition effect of various naphthoquinone compounds on Cdc25s, observed different cell-cycle arrests in HeLa cells (G1/S or G2/M arrest) [69] and an imidazopyridine Cdc25 inhibitor triggered S-phase arrest in MCF-7, HepG2, and HT-29 cell lines [32].

On the other hand, it has been observed that two structurally unrelated Cdc25 inhibitors arrested melanoma cell lines in the G2/M cell-cycle phase and activated an apoptotic program $[35,36,70]$. In addition, in previously published works some terpenoid compounds were tested on A375.S2 human melanoma cell lines. The authors described a different stopping phase of the cell cycle via Cdc25, strictly dependent on the effect of the tested triterpenoid compound [71,72].

Endogenous Cdc25s control cell cycle progression through dephosphorylation via the activation of their natural substrate Cdks. Thus, to directly assess Cdk1 activity in HepG2 cells we used antibodies recognizing phosphorylated Thr14 or Tyr15, two amino acid residues selectively dephosphorylated by Cdc25 in the Cdk1 catalytic domain [69].

In order to investigate the involvement of the inhibition of Cdc25s in the antiproliferative action of J3955, the phosphorylation status of Cdk1 was analyzed after cell exposure to $\mathrm{J} 3955$. 
Western blot analysis of the lysate from HepG2 cells treated with J3955 at $0.75 \mu \mathrm{M}$, $1.5 \mu \mathrm{M}$, and $3 \mu \mathrm{M}$ for $6 \mathrm{~h}$ showed a significant dose-dependent accumulation of the phosphorylated form of Cdk1, when compared to control cell lysates (Figure 10). Considering that an increase in the phosphorylated protein fraction results in a decrease in the nonphosphorylated and active protein fraction, with the amount of total protein being almost unchanged along the different treatments, our results indicate that J3955 may impair Cdk1 activity in exposed cells and suggests its specific influence in molecular mechanisms involving Cdc25 proteins.

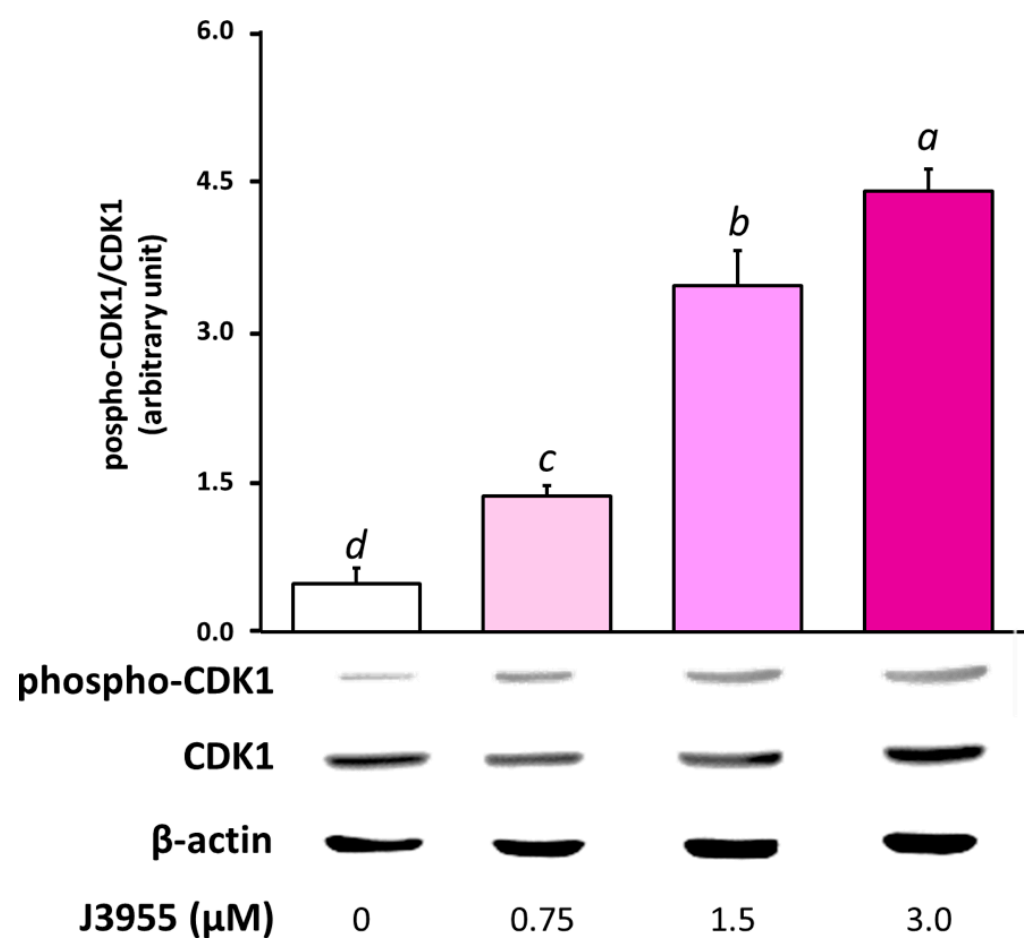

Figure 10. Effects of a $6 \mathrm{~h}$ treatment with $\mathrm{J} 3955(0.75,1.5$, and $3 \mu \mathrm{M})$ on Cdk1 phosphorylation in HepG2 cells. After the treatment, cells were collected and the proteins were isolated for Western blot analysis as described in "Materials and methods". The panel shows a representative Western blot and densitometric analysis. The values represent the ratio between phospho-Cdk1 and total Cdk1, both previously normalized for the corresponding $\beta$-actin. Values are expressed as the mean \pm S.D. of three separate experiments with similar results. Different lowercase letters on the top of each histogram indicate statistical $(p<0.05)$ differences among the tested samples, as measured by one-way ANOVA followed by the Tuckey test. The letter "a" marks the highest value. Bars not sharing the same letter were significantly different.

\section{Materials and Methods}

\subsection{In Silico Insights}

Hardware: the DRUDIT WEB service runs on four servers that are automatically selected according to the number of jobs and online availability. Each server can support up to ten simultaneous jobs, while the exceeding jobs are placed in a queue. Software: DRUDIT consists of several software modules implemented in C and JAVA running on MacOS Mojave. DRUDIT is based on molecular descriptors and represents the evolution of previous automated and online available tools [73,74]. The molecular descriptor tool (MOLDESTO) that we implemented in DRUDIT is a new tool currently able to deal with more than 1400 molecular descriptors. MOLDESTO is able to read common molecules file formats, such as SMILES, SDF, Inchi, Mdl, and Mol2, to optimize structures, and is provided with a caching system to boost the calculation speed of previously submitted structures. Input structures can be drawn in the web application or uploaded to the 
server as external files. In either case, structures are optimized by MOPAC before being processed by MOLDESTO. The binding database (Bdb) [51] focuses on $\mathrm{Ki}, \mathrm{Kd}, \mathrm{IC}_{50}$, and $\mathrm{EC}_{50}$ values, related to a well-defined protein target $[75,76]$. The database of purchasable molecules submitted to in silico screening contains 10,715 structures, retrieved from the Sigma-Aldrich repository.

\subsection{Induced Fit Docking}

The IFD (induced-fit docking) was applied by means of the Schrödinger software suite [77-80] by using the settings from previous works [81,82]. Cdc25B atomic coordinates were downloaded from the Protein Data Bank (PDB id, 1QB0) and refined by the Protein Preparation Wizard module to apply default parameters [83]. The IFD score, which accounts for both the protein-ligand interaction energy and the total energy of the system, is calculated weighing 95\% of Glide Gscore and 5\% of Prime Energy. It is used to rank the IFD poses considering that the more negative the IFD score, the more favorable the binding [84-88].

\subsection{Cdc25s Phosphatase Inhibitory Activity Assay}

The inhibitory activity of the selected compounds for Cdc25s was assessed using the CycLex protein phosphatase Cdc25A, -B, and -C fluorometric assay Kit (CycLex, Cat. No. CY-1355) in accordance with the manufacturer's protocol. The assay is based on the competition of the test compound for O-methyl-fluorescein phosphate (OMFP), an exclusive fluorescence Cdc25 substrate.

An assay mixture containing OMFP was freshly prepared following the kit instructions. Test compounds were previously dissolved in DMSO to obtain stock solutions at $20 \mathrm{mM}$ and kept at $-20{ }^{\circ} \mathrm{C}$. Working solutions of each compound were freshly prepared in the assay buffer. In each well, $40 \mu \mathrm{L}$ of assay mixture was mixed with $5 \mu \mathrm{L}$ of the test compound. The reaction was initiated by adding $5 \mu \mathrm{L}(0.1 \mu \mathrm{g} / \mu \mathrm{L})$ of the purified recombinant $\mathrm{Cdc} 25$ $(\mathrm{Cdc} 25 \mathrm{~A},-\mathrm{B}$, and $-\mathrm{C})$ proteins and mixing thoroughly. The plate was incubated at room temperature for $15 \mathrm{~min}$. Then, $25 \mu \mathrm{L}$ of stop solution was added. Phosphatase activity was measured in a 96-well microtiter plate using a Cdc25s substrate. Fluorescence intensity (FI) was measured using a GloMax ${ }^{\circledR}$-Multi Microplate Reader equipped with a GloMax ${ }^{\circledR}$. Multi Fluorescence Module (Promega Corporation, Madison, WI, USA) with an excitation wavelength of $485 \mathrm{~nm}$ and an emission wavelength of $580 \mathrm{~nm}$. The background was defined as the FI generated from the wells that did not contain Cdc25s but were incubated with the assay mixture. The percentage enzyme activity of the test sample with respect to the control (OMFP wells) was calculated using the following equation:

$$
\% \mathrm{FI}=(\text { FI test sample } / \mathrm{FI} \text { control }) \times 100
$$

$\mathrm{IC}_{50}$ was defined as the concentration of the compound at which there was $50 \% \mathrm{FI}$ of the OMFP wells.

\subsection{Cell Culture}

The cancer cell line HepG2 (hepatocarcinoma cells) was obtained from the American Type Culture Collection (ATCC) (Rockville, MD, USA). The cells were cultured in RPMI supplemented with $5 \%(v / v)$ FBS, $2 \mathrm{mM}$ L-glutamine, $50 \mathrm{IU} / \mathrm{mL}$ penicillin, and $50 \mu \mathrm{g} / \mathrm{mL}$ streptomycin, and maintained in a humidified atmosphere with $5 \% \mathrm{CO}_{2}$ at $37^{\circ} \mathrm{C}$. Cells were routinely cultured in $75 \mathrm{~cm}^{2}$ culture flasks and were trypsinized using trypsin-EDTA. Exponentially growing cells were used for experiments.

\subsection{Anticancer Evaluation Assay}

The selected derivatives were submitted to the MTT assay to assess the growth inhibition activity against HepG2 cells. The MTT assay is a measurement of cell metabolic activity, quite effective in estimating cell proliferation, that is based on the protocol first described by Mosmann [89]. The assay was performed as previously described [90]. Briefly, 
the cells were seeded into a series of standard 96-well plates in $100 \mu \mathrm{L}$ of complete culture medium at $1.5 \times 10^{4}$ cells $/ \mathrm{cm}^{2}$. Cells were incubated for $24 \mathrm{~h}$ under $5 \% \mathrm{CO}_{2}$ at $37^{\circ} \mathrm{C}$ and the medium was then replaced with $100 \mu \mathrm{L}$ of fresh medium supplemented by $5 \%(v / v)$ FBS containing the treatments. The stock solutions $(20 \mathrm{mM})$ were prepared by dissolving selected compounds in DMSO. Working solutions were freshly prepared on the day of testing by diluting the stock solutions in the complete culture medium. For the experiment, we used a concentration range from 20 to $0.02 \mu \mathrm{M}$. Twenty-four hours after seeding, aliquots of $100 \mu \mathrm{L}$ of different solutions at the appropriate concentrations were added to the appropriate wells and the cells were incubated for $48 \mathrm{~h}$ without the renewal of the medium. In each experiment, the DMSO concentration never exceeded $0.25 \%$ and a culture medium with $0.25 \%$ DMSO was used as control. After the incubation time, cells were washed and $50 \mu \mathrm{L}$ FBS-free medium containing $0.5 \mathrm{mg} / \mathrm{mL}$ of MTT was added. The medium was discarded after a $3 \mathrm{~h}$ incubation at $37^{\circ} \mathrm{C}$ and formazan blue formed in the cells was dissolved in DMSO. The absorbance (OD, optical density) at $570 \mathrm{~nm}$ of the MTT-formazan was measured in a microplate reader. As the absorbance is directly proportional to the number of living, metabolically active cells, the percentage of growth (PG) with respect to the untreated cell control for each drug concentration was calculated according to one of the following two equations:

$$
\begin{aligned}
& \text { if (ODtest }- \text { ODtzero }) \geq 0 \text {, then } P G=100 \times(\text { ODtest }- \text { ODtzero }) /(\text { ODctr }- \text { ODtzero }) \\
& \text { if }(\text { ODtest }- \text { ODtzero })<0 \text {, then } P G=100 \times(\text { ODtest }- \text { ODtzero }) / \text { ODtzero }
\end{aligned}
$$

where: ODtzero is the average of the optical density measurements before the exposure of cells to the test compound; ODtest is the average of the optical density measurements after the desired period of time; and ODctr is the average of the optical density measurements after the desired period of time with no exposure of the cells to the test compound.

The concentration necessary for $50 \%$ of growth inhibition $\left(\mathrm{GI}_{50}\right)$ for each derivative was calculated from concentration-response curve using linear regression analysis, by fitting the test concentrations that give PG values above and below the reference value (50\%). Each result was the mean value of three separate experiments performed in quadruplicate. Finally, in order to exclude potential cytotoxic effects at the concentration range used for our experiments, the Trypan blue exclusion method was employed.

\subsection{Cell-Cycle Analysis}

DNA staining with propidium iodide (PI) and flow cytometry analysis were applied as previously described with the aim to evaluate the effects of the selected derivatives on cell-cycle progression [91]. Briefly, HepG2 cells were seeded on 12-well plates at a density of $2.0 \times 10^{4}$ cells $/ \mathrm{cm}^{2}$, and treated $24 \mathrm{~h}$ after seeding without or with the indicated concentrations of the test compound for 12 or $24 \mathrm{~h}$. Following the treatments, cells were collected, washed in PBS, and stained with staining solution $(20 \mu \mathrm{g} / \mathrm{mL}$ propidium iodide, $200 \mu \mathrm{g} / \mathrm{mL}$ RNAse A, and $0.1 \%$ Triton X-100 in PBS) for $30 \mathrm{~min}$ at $37^{\circ} \mathrm{C}$. The DNA contents of more than 10,000 cells were subjected to fluorescence-activated cell sorting (FACS) analysis (Coulter Epics XLTM, Beckman, Brea, CA, USA), and the percentage of cells belonging to the different compartments of the cell cycle was determined. All experiments were performed in duplicate and reproduced at least two times.

\subsection{Western Blotting}

The phosphorylation status of the Cdk1 was analyzed by Western blotting, as previously reported [92]. Briefly, HepG2 cells were treated with J3955 (1.5, 3, and $6 \mu \mathrm{M})$ for $6 \mathrm{~h}$ and after treatment cells were rinsed twice with ice-cold PBS and harvested by scraping in ice-cold hypotonic lysis buffer (10 mM Hepes, $1.5 \mathrm{mM} \mathrm{MgCl} 2,10 \mathrm{mM} \mathrm{KCl}, 0.5 \mathrm{mM}$ phenylmethylsulfonyl fluoride (PMSF), $1.5 \mathrm{lg} / \mathrm{mL}$ soybean trypsin inhibitor, $7 \mathrm{lg} / \mathrm{mL}$ pepstatin $\mathrm{A}, 5 \mathrm{lg} / \mathrm{mL}$ leupeptin, $0.1 \mathrm{mM}$ benzamidine, and $0.5 \mathrm{mM}$ dithioerythritol (DTT)) and incubated for $15 \mathrm{~min}$ on ice. The lysates were centrifuged at $13,000 \times g$ for $5 \mathrm{~min}$, and 
supernatants were immediately portioned and stored at $-80^{\circ} \mathrm{C}$. The protein concentration was determined using the Bradford protein assay reagent (Bio-Rad, Hercules, CA, USA). Aliquots of cell extracts containing 5-15 $\mu$ g protein were separated on 8-12\% sodium dodecyl sulfate (SDS)-polyacrylamide gel electrophoresis and transferred to a nitrocellulose membrane. Colored molecular weight standards (Amersham) were run simultaneously. The immunoblot was incubated overnight at $4{ }^{\circ} \mathrm{C}$ with blocking solution $(5 \%$ skim milk), followed by incubation with either an anti-Cdk1 monoclonal antibody (Invitrogen, Cat: 33-1800), anti-phospho-Cdk1 (Thr14, Tyr15) policlonal antibody (Invitrogen, Carlsbad, CA, USA, Cat: 710840), or anti $\beta$-actin monoclonal antibody (Invitrogene, Cat: MA1-744) as control, for $1 \mathrm{~h}$ at room temperature. Blots were washed two times with Tween 20/Trisbuffered saline (TTBS) and incubated with a 1:1000 dilution of horseradish peroxidase (HRP)-conjugated polyclonal goat anti-mouse IgG antibody (Dako, Glostrup, Denmark), or with a 1:2000 dilution of horseradish peroxidase (HRP)-conjugated polyclonal goat anti-rabbit IgG antibody (Dako) for $1 \mathrm{~h}$ at room temperature.

\subsection{Statistical Analysis}

All data are expressed as mean \pm S.D. Three independent observations were made for each experiment. Statistical difference was calculated using an unpaired Student's $t$-test. Tukey was used to examine the difference between group means.

\section{Conclusions}

The correlation between protein expression pattern and chemosensitivity revealed an innovative and alternative method in the identification of new modulators for the selected targets. Differently from the traditional in silico methods, the proposed protocol allows for the selection of molecular structures with heterogeneous scaffolds, which are not strictly related to the binding sites and with chemical-physical features that can be more suitable for all the pathways involved in the overall mechanism. In this work, we focus our attention on Cdc25 enzymes as crucial targets to halt tumor proliferation. The new mixed ligand structure-based approach permitted, from the evaluation of a database containing more than 10,000 small molecules, the identification of 12 compounds as potential inhibitors of Cdc25s. The biological screenings of the selected structures consolidated and confirmed the in silico results. In particular, the enzymatic inhibition assays showed interesting Cdc25s $\mathrm{IC}_{50}$ values for most of the tested molecules. Among them, J3955, the most active inhibitor of Cdc25s, exhibited antiproliferative activity against HepG2 cells, with $\mathrm{GI}_{50}$ values in the low micromolar range. The flow cytometric analysis, for cell-cycle perturbation experiments, highlighted, after treatment with J3955, cell-cycle arrest and the accumulation of the phosphorylated form of Cdk1.

To gain further insight into the structure-based results, the binding modes of the most interesting compounds were analyzed. The best example, observed by the IFD study (J3955, Figure 11a,b), shows several interactions at the junction between the catalytic pocket and the "swimming pool". In particular, the flat aromatic quinoline scaffold of J3955 is accommodated in the surface of the shallow active site, whereas the flexible and hydrophobic phenylethyl moiety is able to penetrate deeply into the adjacent "pool", where it encounters several apolar residues (Met483, Leu443, Pro444, Leu445, Cys426, and Tyr428). The amidic portion forms several H-bonds with Glu478 (in the catalytic HCX5R motif) and Arg544 (C-terminus, in the "swimming pool") side chains.

Similarly, but with completely different structural features, compound E7887 also could inhibit Cdc25 by binding both to the catalytic cleft (partially occupied by the cyclopentyl ring) and to the "swimming pool", in which the hydrophobic steroid scaffold is inserted (Figure 11c,d). Inside this cavity, $17 \beta-\mathrm{OH}$ stabilized the complex by forming $\mathrm{H}$-bonds with the side $\mathrm{COOH}$ and the backbone $\mathrm{NH}$ of Glu446.

The lack of reactive groups could permit a reversible binding, avoiding the wellestablished toxicity of the quinonoid agents and electrophilic entities. 

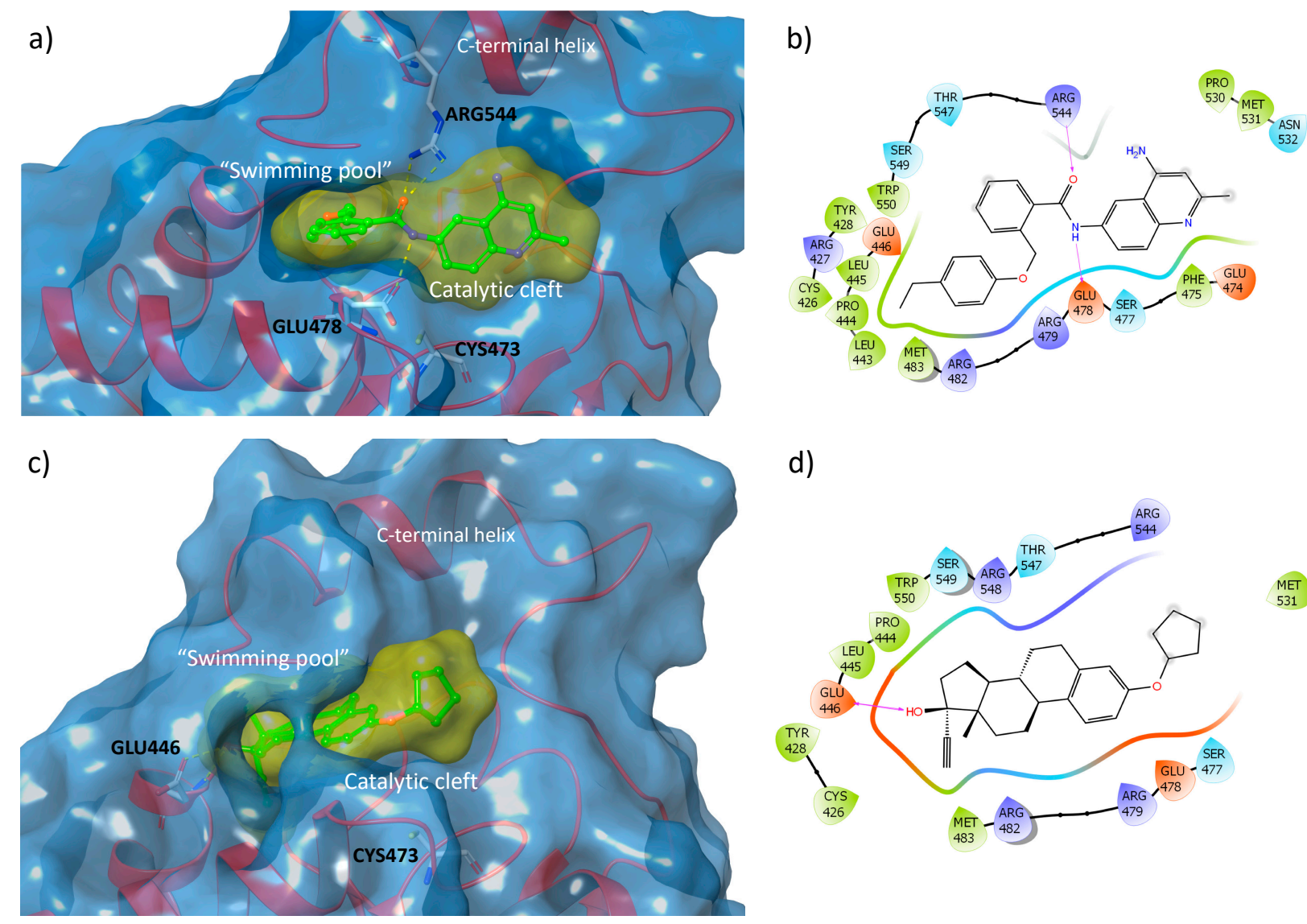

d)

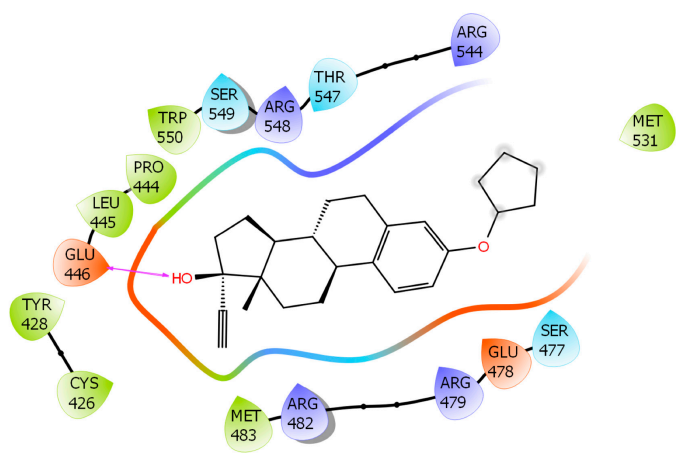

Figure 11. Predicted binding modes of J3955 (a) and of E7887 (c) into the "swimming pool"-catalytic cleft of Cdc25B (PDB id: 1QB0); ligand-protein interaction diagram for J3955-Cdc25B (b) and E7887-Cdc25B (d) complexes, with the hydrogen bond shown as violet arrows.

Supplementary Materials: The following are available online at https:/ /www.mdpi.com/article /10.3390/ijms22073714/s1. Supplementary Material S1: 117 Cdc25 inhibitors selected to build the template. Supplementary Material S2: Cdc25 DAS calculated for purchasable structures database. Supplementary Material S3: 106 selected structure with Cdc25 DAS above 0.8. Supplementary Material S4: Cdc25s normalized NCI expression. Supplementary Material S5: GI$_{50}$ predicted values for the 106 selected structures. Supplementary Material S6: Matching of Cdc25s EP-GI 50 for the 106 selected structures. Supplementary Material S7: Molecular descriptors matrix of the template and selected structures and PCA results. Supplementary Material S8: HRMS data for the in vitro tested compounds. Supplementary Material S9: Dose-response curves for the data presented in Table 3.

Author Contributions: Conceptualization, A.L., S.M., C.G. and D.P.; Data curation, A.L., A.M., G.L.M., G.M. and C.G.; Formal analysis, C.G.; Funding acquisition, A.L.; Methodology, A.L., G.L.M. and G.M.; Resources, G.M.; Software, S.M. and D.P.; Supervision, A.L.; Validation, A.L., A.M., G.L.M. and C.G.; Writing-original draft, A.M., G.L.M., G.M., D.P. and C.G. All authors have read and agreed to the published version of the manuscript.

Funding: This work was in part supported by the PJ_RIC_FFABR_2017_005832 Grant-University of Palermo and by the European Union 2014-2020 PON Ricerca e Innovazione grant from the Italian Ministry of Education, University and Research, entitled "PROGEMA-Processi Green per l’Estrazione di Principi Attivi e la Depurazione di Matrici di Scarto e Non" (ARS01_00432).

Institutional Review Board Statement: Not applicable.

Informed Consent Statement: Not applicable.

Data Availability Statement: The data presented in this study are available on Supplementary Materials.

Conflicts of Interest: The authors declare no conflict of interest. 


\section{References}

1. Russell, P.; Nurse, P. Cdc25+ Functions as an Inducer in the Mitotic Control of Fission Yeast. Cell 1986, 45, 145-153. [CrossRef]

2. Eckstein, J.W. Cdc25 as a Potential Target of Anticancer Agents. Investig. New Drugs 2000, 18, 149-156. [CrossRef] [PubMed]

3. Lindqvist, A.; Källström, H.; Lundgren, A.; Barsoum, E.; Rosenthal, C.K. Cdc25B Cooperates with Cdc25A to Induce Mitosis but has a Unique Role in Activating Cyclin B1-Cdk1 at the Centrosome. J. Cell Biol. 2005, 171, 35-45. [CrossRef] [PubMed]

4. Karlsson-Rosenthal, C.; Millar, J.B. Cdc25: Mechanisms of Checkpoint Inhibition and Recovery. Trends Cell Biol. 2006, 16, $285-292$. [CrossRef] [PubMed]

5. Donzelli, M.; Draetta, G.F. Regulating Mammalian Checkpoints through Cdc25 Inactivation. EMBO Rep. 2003, 4, 671-677. [CrossRef] [PubMed]

6. Lammer, C.; Wagerer, S.; Saffrich, R.; Mertens, D.; Ansorge, W.; Hoffmann, I. The Cdc25B Phosphatase is Essential for the G2/M Phase Transition in Human Cells. J. Cell Sci. 1998, 111 Pt 16, 2445-2453.

7. Lopez-Girona, A.; Furnari, B.; Mondesert, O.; Russell, P. Nuclear Localization of Cdc25 is Regulated by DNA Damage and a 14-3-3 Protein. Nature 1999, 397, 172-175. [CrossRef] [PubMed]

8. Pines, J. Four-Dimensional Control of the Cell Cycle. Nat. Cell Biol. 1999, 1, E73-E79. [CrossRef]

9. Foster, D.A.; Yellen, P.; Xu, L.; Saqcena, M. Regulation of G1 Cell Cycle Progression: Distinguishing the Restriction Point from a Nutrient-Sensing Cell Growth Checkpoint(s). Genes Cancer 2010, 1, 1124-1131. [CrossRef]

10. Mukhopadhyay, S.; Saqcena, M.; Foster, D.A. Synthetic lethality in KRas-driven cancer cells created by glutamine deprivation. Oncoscience 2015, 2, 807-808. [CrossRef]

11. Saqcena, M.; Menon, D.; Patel, D.; Mukhopadhyay, S.; Chow, V.; Foster, D.A. Amino acids and mTOR mediate distinct metabolic checkpoints in mammalian G1 cell cycle. PLOS ONE 2013, 8, e74157. [CrossRef]

12. Sur, S.; Agrawal, D.K. Phosphatases and Kinases Regulating CDC25 Activity in the Cell Cycle: Clinical Implications of CDC25 Overexpression and Potential Treatment Strategies. Mol. Cell. Biochem. 2016, 416, 33-46. [CrossRef]

13. Brenner, A.K.; Reikvam, H.; Lavecchia, A.; Bruserud, Ø. Therapeutic Targeting the Cell Division Cycle 25 (CDC25) Phosphatases in Human Acute Myeloid Leukemia-the Possibility to Target Several Kinases Through Inhibition of the Various CDC25 Isoforms. Molecules 2014, 19, 18414-18447. [CrossRef]

14. Liu, K.; Zheng, M.; Lu, R.; Du, J.; Zhao, Q.; Li, Z.; Li, Y.; Zhang, S. The Role of CDC25C in Cell Cycle Regulation and Clinical Cancer Therapy: A Systematic Review. Cancer Cell Int. 2020, 20, 213. [CrossRef]

15. Rudolph, J. Cdc25 Phosphatases: Structure, Specificity, and Mechanism. Biochemistry 2007, 46, 3595-3604. [CrossRef]

16. Källström, H.; Lindqvist, A.; Pospisil, V.; Lundgren, A.; Rosenthal, C.K. Cdc25A Localisation and Shuttling: Characterisation of Sequences Mediating Nuclear Export and Import. Exp. Cell Res. 2005, 303, 89-100. [CrossRef]

17. Keyse, S.M.; Ginsburg, M. Amino Acid Sequence Similarity between CL100, a Dual-Specificity MAP Kinase Phosphatase and Cdc25. Trends Biochem. Sci. 1993, 18, 377-378. [CrossRef]

18. Aressy, B.; Ducommun, B. Cell Cycle Control by the CDC25 Phosphatases. Anticancer Agents Med. Chem. 2008, 8, 818-824. [CrossRef] [PubMed]

19. Savitsky, P.A.; Finkel, T. Redox Regulation of Cdc25C. J. Biol. Chem. 2002, 277, 20535-20540. [CrossRef]

20. Fauman, E.B.; Cogswell, J.P.; Lovejoy, B.; Rocque, W.J.; Holmes, W.; Montana, V.G.; Piwnica-Worms, H.; Rink, M.J.; Saper, M.A. Crystal Structure of the Catalytic Domain of the Human Cell Cycle Control Phosphatase, Cdc25A. Cell 1998, 93, 617-625. [CrossRef]

21. Reynolds, R.A.; Yem, A.W.; Wolfe, C.L.; Deibel, M.R.; Chidester, C.G.; Watenpaugh, K.D. Crystal Structure of the Catalytic Subunit of Cdc25B Required for G2/M Phase Transition of the Cell Cycle. J. Mol. Biol. 1999, 293, 559-568. [CrossRef] [PubMed]

22. Rudolph, J. Targeting the Neighbor's Pool. Mol. Pharmacol. 2004, 66, 780-782. [CrossRef] [PubMed]

23. Lavecchia, A.; Coluccia, A.; Di Giovanni, C.; Novellino, E. Cdc25B Phosphatase Inhibitors in Cancer Therapy: Latest Developments, Trends and Medicinal Chemistry Perspective. Anticancer Agents Med. Chem. 2008, 8, 843-856. [CrossRef] [PubMed]

24. Lavecchia, A.; Di Giovanni, C.; Novellino, E. CDC25 Phosphatase Inhibitors: An Update. Mini Rev. Med. Chem. 2012, 12, 62-73. [CrossRef]

25. Boutros, R.; Lobjois, V.; Ducommun, B. CDC25 Phosphatases in Cancer Cells: Key Players? Good Targets? Nat. Rev. Cancer 2007, 7, 495-507. [CrossRef]

26. Lazo, J.S.; Aslan, D.C.; Southwick, E.C.; Cooley, K.A.; Ducruet, A.P.; Joo, B.; Vogt, A.; Wipf, P. Discovery and Biological Evaluation of a New Family of Potent Inhibitors of the Dual Specificity Protein Phosphatase Cdc25. J. Med. Chem. 2001, 44, 4042-4049. [CrossRef]

27. Brezak, M.C.; Quaranta, M.; Contour-Galcera, M.O.; Lavergne, O.; Mondesert, O.; Auvray, P.; Kasprzyk, P.G.; Prevost, G.P.; Ducommun, B. Inhibition of Human Tumor Cell Growth in Vivo by an Orally Bioavailable Inhibitor of CDC25 Phosphatases. Mol. Cancer Ther. 2005, 4, 1378-1387. [CrossRef]

28. Cossy, J.; Belotti, D.; Brisson, M.; Skoko, J.J.; Wipf, P.; Lazo, J.S. Biological Evaluation of Newly Synthesized Quinoline-5,8-quinones as Cdc25B Inhibitors. Bioorg. Med. Chem. 2006, 14, 6283-6287. [CrossRef]

29. Lavecchia, A.; Di Giovanni, C.; Pesapane, A.; Montuori, N.; Ragno, P.; Martucci, N.M.; Masullo, M.; De Vendittis, E.; Novellino, E. Discovery of New Inhibitors of Cdc25B Dual Specificity Phosphatases by Structure-Based Virtual Screening. J. Med. Chem. 2012, 55, 4142-4158. [CrossRef] 
30. Ge, Y.; van der Kamp, M.; Malaisree, M.; Liu, D.; Liu, Y.; Mulholland, A.J. Identification of the Quinolinedione Inhibitor Binding Site in Cdc25 Phosphatase B Through Docking and Molecular Dynamics Simulations. J. Comput. Aided Mol. Des. 2017, 31, 995-1007. [CrossRef]

31. Tao, Y.; Hao, X.; Ding, X.; Cherukupalli, S.; Song, Y.; Liu, X.; Zhan, P. Medicinal Chemistry Insights into Novel CDC25 Inhibitors. Eur. J. Med. Chem. 2020, 201, 112374. [CrossRef]

32. Song, Y.; Lin, X.; Kang, D.; Li, X.; Zhan, P.; Liu, X.; Zhang, Q. Discovery and Characterization of Novel Imidazopyridine Derivative CHEQ-2 as a Potent CDC25 Inhibitor and Promising Anticancer Drug Candidate. Eur. J. Med. Chem. 2014, 82, 293-307. [CrossRef]

33. Park, H.; Bahn, Y.J.; Jung, S.K.; Jeong, D.G.; Lee, S.H.; Seo, I.; Yoon, T.S.; Kim, S.J.; Ryu, S.E. Discovery of Novel Cdc25 Phosphatase Inhibitors with Micromolar Activity Based on the Structure-based Virtual Screening. J. Med. Chem. 2008, 51, 5533-5541. [CrossRef]

34. Zhang, S.; Jia, Q.; Gao, Q.; Fan, X.; Weng, Y.; Su, Z. Dual-Specificity Phosphatase CDC25B Was Inhibited by Natural Product HB-21 Through Covalently Binding to the Active Site. Front. Chem. 2018, 6, 531. [CrossRef] [PubMed]

35. Cerchia, C.; Nasso, R.; Mori, M.; Villa, S.; Gelain, A.; Capasso, A.; Aliotta, F.; Simonetti, M.; Rullo, R.; Masullo, M.; et al. Discovery of Novel Naphthylphenylketone and Naphthylphenylamine Derivatives as Cell Division Cycle 25B (CDC25B) Phosphatase Inhibitors: Design, Synthesis, Inhibition Mechanism, and in Vitro Efficacy against Melanoma Cell Lines. J. Med. Chem. 2019, 62, 7089-7110. [CrossRef]

36. Aliotta, F.; Nasso, R.; Rullo, R.; Arcucci, A.; Avagliano, A.; Simonetti, M.; Sanità, G.; Masullo, M.; Lavecchia, A.; Ruocco, M.R.; et al. Inhibition Mechanism of Naphthylphenylamine Derivatives Acting on the CDC25B Dual Phosphatase and Analysis of the Molecular Processes Involved in the High Cytotoxicity Exerted by One Selected Derivative in Melanoma Cells. J. Enzyme Inhib. Med. Chem. 2020, 35, 1866-1878. [CrossRef]

37. Zhang, J.; Ji, F.J.; Gu, Y.; Zhang, X.Y.; Qiao, S.X. Chalcones Derivatives as Potent Cell Division Cycle 25B Phosphatase Inhibitors. Pharmacol. Rep. 2014, 66, 515-519. [CrossRef]

38. Huber-Villaume, S.; Revelant, G.; Sibille, E.; Philippot, S.; Morabito, A.; Dunand, S.; Chaimbault, P.; Bagrel, D.; Kirsch, G.; Hesse, S.; et al. 2-(Thienothiazolylimino)-1,3-thiazolidin-4-ones Inhibit Cell Division Cycle 25 A Phosphatase. Bioorg. Med. Chem. 2016, 24, 2920-2928. [CrossRef]

39. Li, H.L.; Ma, Y.; Li, Y.; Chen, X.B.; Dong, W.L.; Wang, R.L. The Design of Novel Inhibitors for Treating Cancer by Targeting CDC25B through Disruption of CDC25B-CDK2/Cyclin A Interaction Using Computational Approaches. Oncotarget 2017, 8 , 33225-33240. [CrossRef]

40. Kristjánsdóttir, K.; Rudolph, J. Cdc25 Phosphatases and Cancer. Chem. Biol. 2004, 11, 1043-1051. [CrossRef]

41. Galaktionov, K.; Lee, A.K.; Eckstein, J.; Draetta, G.; Meckler, J.; Loda, M.; Beach, D. CDC25 Phosphatases as Potential Human Oncogenes. Science 1995, 269, 1575-1577. [CrossRef]

42. Cangi, M.G.; Cukor, B.; Soung, P.; Signoretti, S.; Moreira, G.; Ranashinge, M.; Cady, B.; Pagano, M.; Loda, M. Role of the Cdc25A Phosphatase in Human Breast Cancer. J. Clin. Investig. 2000, 106, 753-761. [CrossRef] [PubMed]

43. Nishioka, K.; Doki, Y.; Shiozaki, H.; Yamamoto, H.; Tamura, S.; Yasuda, T.; Fujiwara, Y.; Yano, M.; Miyata, H.; Kishi, K.; et al. Clinical Significance of CDC25A and CDC25B Expression in Squamous Cell Carcinomas of the Oesophagus. Br. J. Cancer 2001, 85, 412-421. [CrossRef] [PubMed]

44. Takemasa, I.; Yamamoto, H.; Sekimoto, M.; Ohue, M.; Noura, S.; Miyake, Y.; Matsumoto, T.; Aihara, T.; Tomita, N.; Tamaki, Y.; et al. Overexpression of CDC25B Phosphatase as a Novel Marker of Poor Prognosis of Human Colorectal Carcinoma. Cancer Res. 2000, 60, 3043-3050.

45. Broggini, M.; Buraggi, G.; Brenna, A.; Riva, L.; Codegoni, A.M.; Torri, V.; Lissoni, A.A.; Mangioni, C.; D’Incalci, M. Cell CycleRelated Phosphatases CDC25A and B Expression Correlates with Survival in Ovarian Cancer Patients. Anticancer Res. 2000, 20, 4835-4840.

46. Kudo, Y.; Yasui, W.; Ue, T.; Yamamoto, S.; Yokozaki, H.; Nikai, H.; Tahara, E. Overexpression of Cyclin-dependent Kinaseactivating CDC25B Phosphatase in Human Gastric Carcinomas. Jpn. J. Cancer Res. 1997, 88, 947-952. [CrossRef]

47. Gasparotto, D.; Maestro, R.; Piccinin, S.; Vukosavljevic, T.; Barzan, L.; Sulfaro, S.; Boiocchi, M. Overexpression of CDC25A and CDC25B in Head and Neck Cancers. Cancer Res. 1997, 57, 2366-2368.

48. Zhang, Z.; Zhang, G.; Kong, C. High Expression of Cdc25B and Low Expression of 14-3-3б is Associated with the Development and Poor Prognosis in Urothelial Carcinoma of Bladder. Tumor Biol. 2014, 35, 2503-2512. [CrossRef]

49. Boutros, R.; Dozier, C.; Ducommun, B. The When and Wheres of CDC25 Phosphatases. Curr. Opin. Cell Biol. 2006, 18, 185-191. [CrossRef]

50. Lauria, A.; Mannino, S.; Gentile, C.; Mannino, G.; Martorana, A.; Peri, D. DRUDIT: Web-Based DRUgs DIscovery Tools to Design Small Molecules as Modulators of Biological Targets. Bioinformatics 2020, 36, 1562-1569. [CrossRef]

51. Liu, T.; Lin, Y.; Wen, X.; Jorissen, R.N.; Gilson, M.K. BindingDB: A Web-Accessible Database of Experimentally Determined Protein-Ligand Binding Affinities. Nucleic Acids Res. 2007, 35, D198-D201. [CrossRef]

52. Molecular Targets. Available online: https://dtp.cancer.gov/databases_tools/molecular_target/default.htm (accessed on 1 April 2021).

53. Lavecchia, A.; Cosconati, S.; Limongelli, V.; Novellino, E. Modeling of Cdc25B Dual Specifity Protein Phosphatase Inhibitors: Docking of Ligands and Enzymatic Inhibition Mechanism. ChemMedChem 2006, 1, 540-550. [CrossRef]

54. Lund, G.; Dudkin, S.; Borkin, D.; Ni, W.; Grembecka, J.; Cierpicki, T. Inhibition of CDC25B Phosphatase through Disruption of Protein-Protein Interaction. ACS Chem. Biol. 2015, 10, 390-394. [CrossRef] [PubMed] 
55. Baell, J.B.; Holloway, G.A. New Substructure Filters for Removal of Pan Assay Interference Compounds (PAINS) From Screening Libraries and for Their Exclusion in Bioassays. J. Med. Chem. 2010, 53, 2719-2740. [CrossRef]

56. Lipinski, C.A.; Lombardo, F.; Dominy, B.W.; Feeney, P.J. Experimental and Computational Approaches to Estimate Solubility and Permeability in Drug Discovery and Development Settings. Adv. Drug Deliv. Rev. 2001, 46, 3-26. [CrossRef]

57. Veber, D.F.; Johnson, S.R.; Cheng, H.Y.; Smith, B.R.; Ward, K.W.; Kopple, K.D. Molecular Properties that Influence The Oral Bioavailability of Drug Candidates. J. Med. Chem. 2002, 45, 2615-2623. [CrossRef]

58. Egan, W.J.; Merz, K.M.; Baldwin, J.J. Prediction of Drug Absorption Using Multivariate Statistics. J. Med. Chem. 2000, 43, 3867-3877. [CrossRef]

59. Daina, A.; Michielin, O.; Zoete, V. SwissADME: A Free Web Tool to Evaluate Pharmacokinetics, Drug-Likeness and Medicinal Chemistry Friendliness of Small Molecules. Sci. Rep. 2017, 7, 42717. [CrossRef]

60. Huber, K.V.; Salah, E.; Radic, B.; Gridling, M.; Elkins, J.M.; Stukalov, A.; Jemth, A.S.; Göktürk, C.; Sanjiv, K.; Strömberg, K.; et al. Stereospecific Targeting of MTH1 by (S)-Crizotinib as an Anticancer Strategy. Nature 2014, 508, 222-227. [CrossRef]

61. Hashiguchi, K.; Hayashi, M.; Sekiguchi, M.; Umezu, K. The Roles of Human MTH1, MTH2 and MTH3 Proteins in Maintaining Genome Stability under Oxidative Stress. Mutat. Res. 2018, 808, 10-19. [CrossRef]

62. McPherson, L.A.; Troccoli, C.I.; Ji, D.; Bowles, A.E.; Gardiner, M.L.; Mohsen, M.G.; Nagathihalli, N.S.; Nguyen, D.M.; Robbins, D.J.; Merchant, N.B.; et al. Increased MTH1-Specific 8-oxodGTPase Activity is a Hallmark of Cancer in Colon, Lung and Pancreatic Tissue. DNA Repair 2019, 83, 102644. [CrossRef] [PubMed]

63. Savickiene, J.; Borutinskaite, V.V.; Treigyte, G.; Magnusson, K.E.; Navakauskiene, R. The Novel Histone Deacetylase Inhibitor BML-210 Exerts Growth Inhibitory, Proapoptotic and Differentiation Stimulating Effects on the Human Leukemia Cell Lines. Eur. J. Pharmacol. 2006, 549, 9-18. [CrossRef] [PubMed]

64. Borutinskaite, V.V.; Magnusson, K.E.; Navakauskiene, R. Histone Deacetylase Inhibitor BML-210 Induces Growth Inhibition and Apoptosis and Regulates HDAC and DAPC Complex Expression Levels in Cervical Cancer Cells. Mol. Biol. Rep. 2012, 39, 10179-10186. [CrossRef]

65. Jaschevatzky, O.E.; Anderman, S.; Shalit, A.; Kampf, D.; Grünstein, S. The Treatment of Postmenopausal Syndrome by Monthly Oral Doses of Quinestrol. Acta Obstet. Gynecol. Scand. 1979, 58, 175-178. [CrossRef]

66. Zheng, C.J.; Yang, L.L.; Liu, J.; Zhong, L. JTC-801 Exerts Anti-Proliferative Effects in Human Osteosarcoma Cells by Inducing Apoptosis. J. Recept. Signal Transduct. Res. 2018, 38, 133-140. [CrossRef]

67. Zhao, B.; Hu, T. JTC-801 Inhibits the Proliferation and Metastasis of the Hep G2 Hepatoblastoma Cell Line by Regulating the Phosphatidylinositol 3-Kinase/Protein Kinase B Signalling Pathway. Oncol. Lett. 2019, 17, 1939-1945. [CrossRef]

68. Riou, P.; Saffroy, R.; Chenailler, C.; Franc, B.; Gentile, C.; Rubinstein, E.; Resink, T.; Debuire, B.; Piatier-Tonneau, D.; Lemoine, A. Expression of T-Cadherin in Tumor Cells Influences Invasive Potential of Human Hepatocellular Carcinoma. FASEB J. 2006, 20, 2291-2301. [CrossRef]

69. Kabakci, Z.; Käppeli, S.; Cantù, C.; Jensen, L.D.; König, C.; Toggweiler, J.; Gentili, C.; Ribaudo, G.; Zagotto, G.; Basler, K.; et al. Pharmacophore-Guided Discovery of CDC25 Inhibitors Causing Cell Cycle Arrest and Tumor Regression. Sci. Rep. 2019, 9, 1335. [CrossRef]

70. Capasso, A.; Cerchia, C.; Di Giovanni, C.; Granato, G.; Albano, F.; Romano, S.; De Vendittis, E.; Ruocco, M.R.; Lavecchia, A. Ligand-Based Chemoinformatic Discovery of a Novel Small Molecule Inhibitor Targeting CDC25 Dual Specificity Phosphatases and Displaying in Vitro Efficacy Against Melanoma Cells. Oncotarget 2015, 6, 40202-40222. [CrossRef]

71. Hsiao, Y.P.; Tsai, C.H.; Wu, P.P.; Hsu, S.C.; Liu, H.C.; Huang, Y.P.; Yang, J.H.; Chung, J.G. Cantharidin Induces G2/M Phase Arrest by Inhibition of Cdc25c and Cyclin A and Triggers Apoptosis Through Reactive Oxygen Species and the Mitochondria-Dependent Pathways of A375.S2 Human Melanoma Cells. Int. J. Oncol. 2014, 45, 2393-2402. [CrossRef]

72. Hung, F.M.; Chen, Y.L.; Huang, A.C.; Hsiao, Y.P.; Yang, J.S.; Chung, M.T.; Chueh, F.S.; Lu, H.F.; Chung, J.G. Triptolide Induces S Phase Arrest Via the Inhibition of Cyclin E and CDC25A and Triggers Apoptosis Via Caspase- and Mitochondrial-Dependent Signaling Pathways in A375.S2 Human Melanoma Cells. Oncol. Rep. 2013, 29, 1053-1060. [CrossRef] [PubMed]

73. Lauria, A.; Tutone, M.; Barone, G.; Almerico, A.M. Multivariate Analysis in the Identification of Biological Targets for Designed Molecular Structures: The BIOTA Protocol. Eur. J. Med. Chem. 2014, 75, 106-110. [CrossRef] [PubMed]

74. Lauria, A.; Tutone, M.; Almerico, A.M. Virtual Lock-and-Key Approach: The in Silico Revival of Fischer Model by Means of Molecular Descriptors. Eur. J. Med. Chem. 2011, 46, 4274-4280. [CrossRef] [PubMed]

75. Gaulton, A.; Bellis, L.J.; Bento, A.P.; Chambers, J.; Davies, M.; Hersey, A.; Light, Y.; McGlinchey, S.; Michalovich, D.; Al-Lazikani, B.; et al. ChEMBL: A Large-Scale Bioactivity Database for Drug Discovery. Nucleic Acids Res. 2012, 40, D1100-D1107. [CrossRef] [PubMed]

76. Wang, Y.; Xiao, J.; Suzek, T.O.; Zhang, J.; Wang, J.; Bryant, S.H. PubChem: A Public Information System for Analyzing Bioactivities of Small Molecules. Nucleic Acids Res. 2009, 37, W623-W633. [CrossRef]

77. Sherman, W.; Beard, H.S.; Farid, R. Use of an Induced Fit Receptor Structure in Virtual Screening. Chem. Biol. Drug Des. 2006, 67, 83-84. [CrossRef]

78. Sherman, W.; Day, T.; Jacobson, M.P.; Friesner, R.A.; Farid, R. Novel Procedure for Modeling Ligand/Receptor Induced Fit Effects. J. Med. Chem. 2006, 49, 534-553. [CrossRef]

79. Maestro, Version 9.3; Schrödinger, LLC: New York, NY, USA, 2012. 
80. Zhong, H.; Tran, L.M.; Stang, J.L. Induced-Fit Docking Studies of the Active and Inactive States of Protein Tyrosine Kinases. J. Mol. Graph. Model. 2009, 28, 336-346. [CrossRef]

81. Martorana, A.; Lauria, A. Design of Antitumor Drugs Targeting c-Kit Receptor by a New Mixed Ligand-Structure Based Method. J. Mol. Graph. Model. 2020, 100, 107666. [CrossRef]

82. Martorana, A.; Gentile, C.; Lauria, A. In Silico Insights into the SARS CoV-2 Main Protease Suggest NADH Endogenous Defences in the Control of the Pandemic Coronavirus Infection. Viruses 2020, 12, 805. [CrossRef] [PubMed]

83. Wang, H.; Aslanian, R.; Madison, V.S. Induced-Fit Docking of Mometasone Furoate and Further Evidence for Glucocorticoid Receptor 17Alpha Pocket Flexibility. J. Mol. Graph. Model. 2008, 27, 512-521. [CrossRef] [PubMed]

84. Friesner, R.A.; Murphy, R.B.; Repasky, M.P.; Frye, L.L.; Greenwood, J.R.; Halgren, T.A.; Sanschagrin, P.C.; Mainz, D.T. Extra Precision Glide: Docking and Scoring Incorporating a Model of Hydrophobic Enclosure for Protein-Ligand Complexes. J. Med. Chem. 2006, 49, 6177-6196. [CrossRef] [PubMed]

85. Halgren, T.A.; Murphy, R.B.; Friesner, R.A.; Beard, H.S.; Frye, L.L.; Pollard, W.T.; Banks, J.L. Glide: A New Approach for Rapid, Accurate Docking and Scoring. 2. Enrichment Factors in Database Screening. J. Med. Chem. 2004, 47, 1750-1759. [CrossRef] [PubMed]

86. Friesner, R.A.; Banks, J.L.; Murphy, R.B.; Halgren, T.A.; Klicic, J.J.; Mainz, D.T.; Repasky, M.P.; Knoll, E.H.; Shelley, M.; Perry, J.K.; et al. Glide: A New Approach for Rapid, Accurate Docking and Scoring. 1. Method and Assessment of Docking Accuracy. J. Med. Chem. 2004, 47, 1739-1749. [CrossRef]

87. Jacobson, M.P.; Friesner, R.A.; Xiang, Z.; Honig, B. On the Role of the Crystal Environment in Determining Protein Side-Chain Conformations. J. Mol. Biol. 2002, 320, 597-608. [CrossRef]

88. Jacobson, M.P.; Pincus, D.L.; Rapp, C.S.; Day, T.J.; Honig, B.; Shaw, D.E.; Friesner, R.A. A Hierarchical Approach to All-Atom Protein Loop Prediction. Proteins 2004, 55, 351-367. [CrossRef]

89. Mosmann, T. Rapid Colorimetric Assay for Cellular Growth and Survival: Application to Proliferation and Cytotoxicity Assays. J. Immunol. Methods 1983, 65, 55-63. [CrossRef]

90. Lauria, A.; Alfio, A.; Bonsignore, R.; Gentile, C.; Martorana, A.; Gennaro, G.; Barone, G.; Terenzi, A.; Almerico, A.M. New Benzothieno[3,2-d]-1,2,3-triazines with Antiproliferative Activity: Synthesis, Spectroscopic Studies, and Biological Activity. Bioorg. Med. Chem. Lett. 2014, 24, 3291-3297. [CrossRef]

91. Martorana, A.; Gentile, C.; Perricone, U.; Piccionello, A.P.; Bartolotta, R.; Terenzi, A.; Pace, A.; Mingoia, F.; Almerico, A.M.; Lauria, A. Synthesis, Antiproliferative Activity, and in Silico Insights of New 3-Benzoylamino-benzo[b]thiophene Derivatives. Eur. J. Med. Chem. 2015, 90, 537-546. [CrossRef]

92. Lauria, A.; Abbate, I.; Gentile, C.; Angileri, F.; Martorana, A.; Almerico, A.M. Synthesis and Biological Activities of a New Class of Heat Shock Protein 90 Inhibitors, Designed by Energy-Based Pharmacophore Virtual Screening. J. Med. Chem. 2013, 56, 3424-3428. [CrossRef] 